\title{
Deep water circulation and composition in the Arctic Ocean by dissolved barium, aluminium and silicate
}

T. Roeske ${ }^{\mathrm{a} *}$, M. Rutgers vd Loeff $f^{\mathrm{a}}$, R. Middag ${ }^{\mathrm{b}, \mathrm{c}}$, K. Bakker $^{\mathrm{b}}$

${ }^{a}$ Alfred Wegener Institut für Polar- und Meeresforschung (AWI), Germany

${ }^{\mathrm{b}}$ Royal Netherlands Institute for Sea Research (Royal NIOZ), The Netherlands

c Department of Ocean Sciences \& Institute of Marine Sciences, University of California Santa Cruz, CA 95064, USA

*Corresponding author:

Tobias Roeske c/o Michiel Rutgers van der Loeff

Alfred Wegener Institute for Polar and Marine Research (AWI)

Am Handelshafen 12

27570 Bremerhaven, Germany

E-Mail: mloeff@awi.de

Phone: +49 47148311611

Fax: +49 47148311425

Published as

Marine Chemistry 132-133 (2012) 56-67, doi 10.1016/j.marchem.2012.02.001 


\begin{abstract}
As part of the ARK-XXII/2 Polarstern expedition in summer 2007, dissolved Ba was analyzed in the Eurasian Basins and the Makarov Basin including the Alpha and Mendeleyev Ridges as well as on the adjacent shelves. The data was compared with data of dissolved Al and Si from the same cruise. Superimposed on the gradual increase of concentration with depth by dissolution of the particle rain, we observe different flow patterns in intermediate waters along the track. In the Atlantic and Intermediate Depth Water (AIDW) in the Amundsen Basin the influence from Eurasian shelf water can be seen in slightly enhanced concentrations of dissolved $\mathrm{Ba}$ compared with $\mathrm{Al}$ and $\mathrm{Si}$. At the same time Al concentrations decrease with distance from the Eurasian shelves. Source waters to the Atlantic Layer Water (ALW) in the Makarov Basin have the same background Ba concentrations as the Nansen AIDW. We describe the distributions of the elements in the Deep Eurasian and Bottom Water (DEBW) by deep shelf convection as well as diffusion from sediments controlling concentrations in the Nansen DEBW while in the Amundsen DEBW diffusion from sediments appears to be more important. In the Makarov Basin inflow from the Canadian Basin and overflow from the Amundsen Basin at $2000 \mathrm{~m}$ depth at the Lomonosov Ridge are required to explain the composition of bottom waters.
\end{abstract}

Keywords: Barium; Arctic Ocean; hydrography; regeneration; GEOTRACES 


\section{Introduction}

The Arctic Ocean covers an area $9.6 \cdot 10^{6} \mathrm{~km}^{2}$ (Serreze et al., 2006) corresponding to $5 \%$ of the world oceans but only $1.5 \%$ in volume (Guay and Falkner, 1998a). One third of this area contributes to the shelf seas. About $10 \%$ of the world's river discharge flows into the Arctic Ocean making it one of the most important estuarine systems (Aagaard and Carmack, 1989; Dickson et al., 2007). These contribute to the fresh surface layer of the Arctic Ocean. This Surface Mixed Layer with temperatures close to the freezing point of seawater is overlying a strong cold and low salinity halocline (Aagaard et al., 1981), which is maintained by waters advected from the shelf seas. Processes on the shelves modify the properties of source waters and altered tracer fields provide the means to determine both the nature of shelf processes and to deduce mean circulation of the Arctic (Abrahamsen et al., 2009; Falkner et al., 1994b; Rutgers van der Loeff et al., 2003; Rutgers van der Loeff et al., 1995). Shelf waters exert a strong influence on the structure of the Arctic halocline through their role in distributing freshwater between the Arctic basins (Abrahamsen et al., 2009; Steele and Boyd, 1998).

The largest freshwater inventory is found in the upper $300 \mathrm{~m}$ of the Canadian Basin (e.g. Yamamoto-Kawai et al., 2008; Rabe et al., 2011). Atlantic waters entering the Arctic Ocean via the West Spitsbergen Current and Barents and Kara Seas are forming a boundary current modified by shelf processes. One branch of this halocline water crosses over the Lomonosov Ridge while another branch flows along the Lomonosov Ridge in the Amundsen Basin towards the Fram Strait (Anderson et al., 1994; Rudels et al., 2000). Atlantic waters may be identified in a depth of 150 to $600 \mathrm{~m}$ throughout the Arctic Ocean by a temperature maximum. Pacific water entering the Arctic Ocean through Bering Strait contributes to the surface and halocline waters of the Canadian Basin (Bauch et al., 1995). The halocline may be divided into an upper and a lower halocline using salinity and nutrients. Salinities of 32.5 to 33.5 and a nutrient maximum imprinted in the Chukchi and East Siberian Seas characterize the Pacific origin of the upper halocline (Jones and Anderson, 1986; Jones et al., 1991; Kinney and Burrell, 1970; Moore et al., 1983; Morison et al., 1998). Pacific waters of winter origin tend to enter the interior Arctic below the upper mixed layer because they are generally more saline (Weingartner et al., 1998). The water column of the Makarov Basin and surface waters of the Amundsen Basin are influenced by Pacific inflow (Anderson et al., 1994; Rudels et al., 2000). The lower halocline is formed on the shelves of the Barents and Kara Seas (Jones and Anderson, 1986; Jones et al., 1991) and is characterized by salinities of 34.2 to 34.4 and a pronounced NO minimum (Broecker, 1974; Jones and Anderson, 1986). These waters are divided further on into a Barents Sea branch halocline and a Fram Strait branch halocline (Rudels et al., 2004). While the lower halocline is observed throughout the entire Arctic Ocean the upper halocline is primarily restricted to the Canadian Basin (Jones and Anderson, 1986; Jones et al., 1991). Underneath these halocline waters intermediate waters down to about $2000 \mathrm{~m}$ as well as deep and bottom waters are located. Bottom waters are influenced by dense water convecting down the slopes after formation on the shelves (Anderson et al., 1994; Rudels et al., 2000). Waters carrying a terrigenous signal were suggested to be formed by boundary processes at the edges of Arctic shelves and sinking particles (Moore and Dymond, 1991; Moran and Moore, 1991). Diffusion from particles of the Barents and the Kara Seas as well as diffusion from the underlying sediments are important sources. These particles are transported here by convection of dense shelf-derived water into the basins. This water is formed 
by sea ice formation, brine rejection, and dense water formation in Barents and Kara Seas (Rudels et al., 2000; Rusakov et al., 2004). Water convecting downwards mixes with the boundary current (Rudels et al., 2000) and picks up more sediment (Moran and Moore, 1991) contributing to concentrations of $\mathrm{Ba}$ and other trace elements by partial dissolution of these particles. Slope convection is highest at Severnaya ZemIya (Rudels et al., 2000). By comparing $\delta^{18} \mathrm{O}$ values Bauch et al. (1995) show that the main source regions for the Deep European and Bottom Water (DEBW) are the Barents and Kara Seas since only these do not have a considerable river-runoff inventory while the source regions for Deep Makarov and Makarov Bottom Water (DMBW) lie on the eastern shelves.

We know many aspects of hydrography but we still have major gaps in our knowledge especially in the circulation of deep water and in the formation of deep water from entrained shelf waters. Ba is known to be supplied by rivers. The Ba content in the rivers on the Canadian side (Mackenzie) is much higher than on the Siberian side. Ba is used by various authors, together with salinity, $\delta^{18} \mathrm{O}$, nutrients (and potentially other river-supplied components), to distinguish fresh water sources in the Arctic (Abrahamsen et al., 2009; Falkner et al., 1994b; Guay and Falkner, 1998b; Guay et al., 2009; Taylor et al., 2003). This will be discussed in detail in a parallel paper on surface waters (Roeske et al., submitted). More generally, and similar to Radium, $\mathrm{Ba}$ in the open ocean can be regarded as a tracer of shelf waters (Moore and Dymond, 1991; Moore and Shaw, 2008; Rutgers van der Loeff et al., 1995). Potentially, Ba could therefore be expected to trace any shelf-derived signals into the deep ocean. This is comparable to a recent paper by Middag et al. (2009) where the distribution of $\mathrm{Al}$ in deep waters of the Arctic Ocean was interpreted in the light of deep water formation. Here we investigate relationships between $\mathrm{Ba}, \mathrm{Si}$, and $\mathrm{Al}$ in an attempt to distinguish between signals produced by the regeneration of sinking particles and signals derived from entrainment of shelf waters. Moreover we investigate whether the relationships between $\mathrm{Ba}, \mathrm{Si}$ and $\mathrm{Al}$ differ between water masses and between the various deep Arctic Basins, and whether these differences can help us to infer deep water circulation and shelf water inputs.

\section{Methods}

The methods following Falkner et al. (1993) are described in detail in Roeske et al. (submitted). While in that paper we concentrate on surface water concentrations, here we describe full depth profiles excluding the surface layer. Water samples were collected during Polarstern expedition ARK-XXII/2 in summer of 2007. The sampled area reaches from the Barents Sea to the Nansen Basin to the Kara Sea and then to the Makarov Basin and finally the Laptev Sea (Schauer, 2008) (table 1, fig. 1). There were 40 vertical profiles with about 450 samples for Ba, using an ultra-clean Titanium-rosette with $12 \mathrm{~L}$ bottles from Royal NIOZ (De Baar et al., 2008). $15 \mathrm{ml}$ LDPE bottles were used to collect samples for $\mathrm{Ba}$. The bottles were pre-rinsed thrice with the water to be sampled. Unfiltered samples were acidified with $30 \mu \mathrm{l}$ quartz distilled $\mathrm{HCl}$ and afterwards tightly sealed with parafilm and stored at room temperature. An additional set of filtered samples was analyzed in 2009 from samples archived by the NIOZ team.

Ba was analyzed using an isotope dilution procedure (Falkner et al., 1993; Guay and Falkner, 1998b; Klinkhammer and Chan, 1990) and then measured with a ThermoFinnigan Element2 high resolution sector field inductively coupled plasma mass spectrometer (SF-ICP-MS). A ${ }^{135}$ Ba-enriched solution (produced from $\mathrm{BaCO}_{3}$ from 
Spex Industry) was calibrated using commercial ICP-MS standard solutions (Spetec $($ single element Ba for ICP-MS and NIST standard reference material $(1643 e)$. Aliquots of $500 \mu \mathrm{l}$ were spiked with this ${ }^{135} \mathrm{Ba}$-enriched solution to obtain a ${ }^{138} \mathrm{Ba} /{ }^{135} \mathrm{Ba}$ ratio between 0.7 to 1 to minimize error propagation (Klinkhammer and Chan, 1990) and diluted hundredfold using 18.2 M $\Omega$ water. Spiking and dilution were done gravimetrically. About $1 \mathrm{ml}$ of the samples were introduced via autosampler $(\sim 200 \mu \mathrm{l} / \mathrm{min}$ uptake) to a micro-concentric Teflon $®$ nebulizer and an Apex® Q quartz desolvation chamber. The SF-ICP-MS was operated in peak jump mode and data were accumulated in three $20 \mathrm{~s}$ intervals for masses 135, 137, and 138. The SF-ICPMS was operated in low resolution mode $(\Delta \mathrm{m} \sim 300)$. A three minute wash-out with 1 $\mathrm{M}$ double distilled $\mathrm{HNO}_{3}$ was followed by a $90 \mathrm{sec}$. take-up time to make memory effects negligible. A blank and a monitor for mass-bias correction (Canadian certified reference material CRM NASS-5) bracketed every five samples. In addition, in every tray of 19 samples at least two standards were included to check consistency. Random repeats of two samples were also done in each run. Samples were analyzed twice. If duplicates varied by more than the calculated maximum method error, samples were prepared and analyzed anew. Sensitivity of the SF-ICP-MS resulted in about $200000 \mathrm{cps}{ }^{138} \mathrm{Ba}$ in samples of Atlantic background. Blanks always were below $2000 \mathrm{cps}$ being usually below $1000 \mathrm{cps}$. An interlab analysis (with three additional labs) to test the accuracy, using various standard materials (SLRS-3, 4, 5, OMP, Spetec $\AA$ single element Ba for ICP-MS, NIST standard reference material ${ }^{\circledR} 1643 e$ ) as reference for the calibration of the ${ }^{135} \mathrm{Ba}$ standard is described in Roeske et al. (submitted). Similar to Taylor et al. (2003), who discovered problems with the stoichiometry of the starting salts of commercial $\mathrm{BaCO}_{3}$ standards and thus used archived GEOSECS standards, there was a systematic offset between results of commercial standards and natural standards as absolute reference. Our data, as those of Roeske et al. (submitted), rely on calibration using commercial standards (Spetec $®$ single element Ba for ICP-MS, NIST standard reference material $\left.{ }^{\circledR} 1643 e\right)$, checked by data from a procedure used for almost all published data on dissolved $\mathrm{Ba}$ in the Arctic (cf. Falkner et al., 1993; 1994; Guay and Falkner 1998b; Taylor et al., 2003; Abrahamsen et al., 2009).

Ba concentrations were calculated following Klinkhammer and Chan (1990):

$$
[\mathrm{Ba}]\left(\mathrm{nmol} \cdot \mathrm{g}^{-1}\right)=\frac{\left(R_{m}-R_{s p k}\right)\left[{ }^{135_{B}} \mathrm{Ba}\right] W_{s p k}}{\left(1-\frac{R_{m}}{R_{\text {nat }}}\right) A_{138} W_{\text {sam }}}
$$

where $R_{m}$ = ratio measured, $R_{\text {nat }}=$ the naturally occurring ${ }^{138} \mathrm{Ba} /{ }^{135} \mathrm{Ba}$ mass ratio $\left(R_{\text {nat }}\right.$ $=10.877)$, the ${ }^{138} \mathrm{Ba} /{ }^{135} \mathrm{Ba}$ ratio of the spike $\left(R_{s p k}=0.025\right)$, the concentration of ${ }^{135} \mathrm{Ba}$ in the spike solution $\left(\left[{ }^{135} \mathrm{Ba}\right]=9.04 \mathrm{ppb}\right.$ and $9.53 \mathrm{ppb}$ in 2008 and 2009 respectively), the natural abundance of ${ }^{138} \mathrm{Ba}\left(A_{138}=0.7166\right)$ and the weight of the sample $\left(W_{\text {sam }}\right)$ and the spike $\left(W_{s p k}\right)$.

Mass discrimination, called "mass bias", is derived by a method used by Freydier et al. (1995) by measuring the masses 135, 137, and 138 of a natural Ba solution (Canadian CRM NASS-5). It follows a linear law following eqn. 2:

$$
R_{m}=R_{t}(1+n \alpha)
$$

where $R_{m}=$ measured isotopic ratio, $R_{t}=$ true value of this isotopic ratio, $n=$ number of mass units between the two isotopes, and $\alpha=$ unitary mass discrimination. The recommended point and discrimination line is also given by Freydier et al. (1995). 
Calculated maximum error of the method always was below $3 \%$. Precision of repeated analyses of samples and standard solutions was within $1.5 \%$ (1- $\sigma)$. Error of ratio ${ }^{138} \mathrm{Ba} /{ }^{135} \mathrm{Ba}$ was $0.6 \%$ or better.

Regression analyses were done using linear least square regressions and a robust linear regression, namely the 'regress' and 'robustfit' functions by Matlab ${ }^{\circledR}$. Errors of the least square regressions between $\mathrm{Ba}, \mathrm{Al}$ and $\mathrm{Si}$ are given as $95 \%$ confidence level. Regression results are shown in tables 2 to 4 .

Salinity (conductivity), temperature and depth (pressure) were measured on two CTD's, one from the Netherlands Institute for Sea Research (NIOZ) and one from the Alfred Wegener Institute for Polar and Marine Research (AWI), Germany. Both were Sea Bird electronics and calibrated onboard (Schauer, 2008).

Elemental dissolved aluminium data were acquired using a method modified after the method by Resing and Measures (1994). Inorganic nutrients were determined by standard procedures (Grasshoff et al., 1983). In the following the mentioned silicate concentration is equal to the elemental concentration of $\mathrm{Si}$ in seawater. ${ }^{\wedge}$ details are given in Middag et al. (2009).

Figures were created using the Ocean Data View software (Schlitzer, 2010).

\section{Results}

An overview of the elemental dissolved $\mathrm{Ba}$ distribution along the sections is seen in figs. 2 to 4. All Ba data are available in the Pangaea data base (Roeske et al., 2011). To place the Ba sections in their hydrographic context, we refer to Schauer et al. (2008) with regard to salinity and temperature and we refer to Middag et al. (2009) with regard to dissolved $\mathrm{Al}$ and $\mathrm{Si}$. In all sections Ba concentrations of about 41 to 45 $\mathrm{nM}$ show the Atlantic origin of water masses. This lower halocline water reaches the surface in all sections. In the Amundsen and Makarov basin of section $\mathrm{C}$ upper halocline waters with Ba from 45 to $48 \mathrm{nM}$ overlay the lower halocline water (fig. 3). On top of the upper halocline water and on the edge of the Laptev shelf (fig. 4) a layer of fresh water with high concentrations of $\mathrm{Ba}$ is seen (Roeske et al., submitted). In all basins the nutrient-like distribution of $\mathrm{Ba}$ is obvious. Concentrations in DEBW are slightly higher than in DMBW.

Concentrations of $\mathrm{Ba}$ in the upper 150 to $200 \mathrm{~m}$ are strongly influenced by river water, sea ice melt, and bioactivity (Aagaard et al., 1981; Roeske et al., submitted; Steele and Boyd, 1998; Yamamoto-Kawai et al., 2008) (cf. fig. 3). This water mass is referred to as Surface Layer Water (SLW). The average depth of the core of the Atlantic layer determined by the temperature maximum is $150 \mathrm{~m}$. This depth goes down to $300 \mathrm{~m}$ in the Makarov Basin and parts of the Amundsen Basin. Correlations between dissolved $\mathrm{Ba}, \mathrm{Si}$, and $\mathrm{Al}$ are done here from that depth onwards to exclude the varying contributions from rivers, Pacific inflow, ice melt and biological activity at shallower depths. The depths from the temperature maximum to constant temperatures at about $2000 \mathrm{~m}$ (cf. Anderson et al., 1994) will be referred to as Atlantic and Intermediate Depth Water (AIDW). These waters include the Atlantic Layer Water (ALW) from about 150 to $600 \mathrm{~m}$ and the underlying Arctic Intermediate Water (AIW). In waters below $2000 \mathrm{~m}$ we find the Deep European Water and the Bottom Water which we denote together as DEBW (Rutgers van der Loeff et al., 1995; Schlosser et al., 1995). The depth taken is the depth of nearly constant potential temperature 
which is from $-0.85{ }^{\circ} \mathrm{C}$ onwards (Middag et al., 2009) except for the Makarov Basin and the Lomonosov, Alpha, and Mendeleev Ridges where the potential temperature chosen is $-0.50{ }^{\circ} \mathrm{C}$ because temperatures are higher in DMBW.

\subsection{Section A}

Section A (fig. 2) consists of 8 profiles with four being in the Barents Sea ( 200 m), two at the shelf break and two in the Nansen Basin ( $4000 \mathrm{~m})$. Also results from section $B$ are given in this figure (see below).

The southernmost stations in the Barents Sea have temperatures ranging from 4.33 to $6.56{ }^{\circ} \mathrm{C}$. Salinity is from 34.75 to 35.06 , clearly indicating its Atlantic origin. These waters are depleted in nutrients. Temperature and salinity decrease towards the north as waters are mixed with melting sea ice and river water from the Barents Sea. Over the Barents Sea halocline waters are formed by modification of inflowing Atlantic water (Rudels et al., 2004).

Concentrations of Ba range from 30.3 to $49.6 \mathrm{nM}$. They are lowest in surface waters north of Spitsbergen and in the Barents Sea, starting to rise from $500 \mathrm{~m}$ downwards with maximum concentrations at the bottom. In the AIDW concentrations rise from 42.3 to $47.3 \mathrm{nM}$. In DEBW concentrations rise from 47.5 to $49.6 \mathrm{nM}$. One sample at station 258 at $2200 \mathrm{~m}$ depth overlaps with concentrations of the AIDW but this is within errors (46.7 nM).

While on the shelf and in the SLW there is no correlation with Al and Si, below about $150 \mathrm{~m}$ in the Nansen Basin there is (fig. 5, tables 2 \& 3). The slopes and intercepts of the regression lines of Ba vs. Al for the Eurasian AIDW and the Nansen DEBW vary only slightly (fig. 5a). The same is true for $\mathrm{Ba}$ and Si only in the AIDW. The Ba:Si regressions slopes of the Nansen DEBW are higher by a factor of 3.9 in section $A$ compared with the Nansen AIDW (fig. 5b).

\subsection{Section $B$}

Section B only consists of four profiles of which two were close to each other as they were part of a test between the ultra-clean and the normal Rosette cast (see above). In addition there are two surface samples. Data of this section are discussed in combination with section $\mathrm{C}$.

\subsection{Section C}

Section $\mathrm{C}$ consists of 17 profiles from the Kara Sea to the rim of the Canadian Basin just south of the Alpha Ridge. This is the largest section crossing the Nansen Basin, the Amundsen Basin, and the Makarov Basin. There is one profile above the Gakkel Ridge, one above the Alpha Ridge, two above the Lomonosov Ridge and one (station 349) on the Mendeleyev Ridge. Intermediate and deep water samples from the Nansen Basin, Amundsen Basin, and Gakkel Ridge are referred to as Eurasian AIDW or DEBW, respectively. Samples from AIDW of the Lomonosov Ridge, the Makarov Basin, the Alpha Ridge, and the Mendeleyev Ridge are referred to as Canadian AIDW.

In surface waters of the eastern shelf break area of the Kara Sea (Section C) temperature ranges from -1.80 to $-1.40{ }^{\circ} \mathrm{C}$ and salinity from 30.60 to 33.53 , which is not very different from surface waters of the Nansen Basin. In the area of the Kara shelf break (Sections B and C) there is no horizontal gradient seen in temperature and 
salinity like on the Barents and Laptev Sea shelves (sections A and D, respectively), as data from the shelf itself are missing. This is the region where the Barents and Kara Sea branch of the Atlantic water is leaving the shelf at the St. Anna Trough (Rudels et al., 2004). In the area of the western Kara Sea shelf break, temperature ranges from -1.69 to $-1.32{ }^{\circ} \mathrm{C}$ (close to freezing temperatures) in surface waters, salinity is from 32.70 to 33.89 , with nutrients being depleted only in the upper $20 \mathrm{~m}$.

In this section $\mathrm{Ba}$ concentrations not only rise with depth but also in surface waters upon crossing the Lomonosov Ridge into the Makarov Basin. Concentrations in the Eurasian Basins range from 41.4 to $51.6 \mathrm{nM}$ (apart from one exceptionally high value of $52.7 \mathrm{nM}$ in the deep water just below the Kara Sea slope on the Eurasian side). After crossing the Lomonosov Ridge, we found values up to $68 \mathrm{nM}$ in the upper 200 $\mathrm{m}$ of the Makarov Basin. Below this layer concentrations equal those on the Eurasian side but bottom concentrations are lower by about 1 to $2 \mathrm{nM}$ in the DMBW with maximum concentrations of $49.6 \mathrm{nM}$ (fig. 3). At the shelf break of section C, station 285 shows higher $\mathrm{Ba}$ concentrations than away from the slope in the Nansen Basin (fig. 3). In addition $\mathrm{Ba}$ is enriched compared to $\mathrm{Al}$ and Si at station 285 (fig. 6). Compared to surface water, concentrations rise with depth by 5.9 to $6.1 \mathrm{nM}$ in the Eurasian AIDW and $5.9 \mathrm{nM}$ in the Makarov AIDW until $2000 \mathrm{~m}$ depth. Over the Alpha and Mendeleyev Ridges Ba concentrations rise by 3.4 and $1.9 \mathrm{nM}$ respectively until 1500 $\mathrm{m}$ depth. In the DEBW concentrations rise by 2.3 to $3.3 \mathrm{nM}$, in the DMBW by $1.2 \mathrm{nM}$.

In the Nansen Basin correlations with Al and Si are similar to sections A \& B (fig. 5). The Ba:Si regressions show again the remarkable change at about $2000 \mathrm{~m}$ : slopes of the Nansen DEBW are higher by a factor of 5.5 in section B \& C compared with the Nansen AIDW (fig. 5b). Station 285 at the slope of the Kara Sea is not used for regression analyses in the Nansen Basin as will be discussed below.

The data in the Amundsen Basin is sparse resulting in larger errors in regression analyses (fig. 6, table 3). It is not useful to make separate analyses of data of the Amundsen DEBW alone. Ba:Si data scatter around the Nansen DEBW regression line.

In the Makarov Basin we see a different picture (fig. 7). In the Makarov AIDW Ba concentrations are comparable to the Eurasian AIDW but Al concentrations are significantly lower below the ALW resulting in a Ba:Al regression slope higher by a factor of 1.5 compared with the Eurasian AIDW. Ba:Al data of DMBW are close to the extrapolated regression line of the Amundsen AIDW (fig. 6a) and thus significantly different from the Makarov AIDW. Ba:Si data of the DMBW have a slope of 2.6 similar to 2.7 found in the Nansen DEBW of section A (fig. $5 \mathrm{~b}$ ) but concentrations of $\mathrm{Si}$ are an average of $1.1 \mu \mathrm{M}$ higher in the Makarov Basin.

\subsection{Section $D$}

Section D consists of 9 profiles with two being on the Laptev Sea shelf, one at the shelf break and the other 6 following the Gakkel Ridge.

The southernmost station in the Laptev Sea shelf had a surface salinity of only 29.09 and a surface temperature of $0.43^{\circ} \mathrm{C}$, as well as lowest values of nutrients. At the shelf break (stations 402 and 403) nutrients are no longer depleted at the surface. Temperature is close to the freezing point at $-1.62{ }^{\circ} \mathrm{C}$ and salinity 30.75 . Overall, a 
pronounced decrease in temperature and increase in salinity can be seen from south to north in surface waters of the Laptev Sea.

Ba concentrations range from 37.9 up to $96.6 \mathrm{nM}$ in waters of the Laptev Sea shelf and from 42.6 to $50.3 \mathrm{nM}$ in the Eurasian Basins (at station 373 concentrations up to $52.6 \mathrm{nM}$ are found in surface waters). Concentrations increase with depth until the seafloor. Concentrations rise with depth by $5.4 \mathrm{nM}$ in AIDW and by another $2.3 \mathrm{nM}$ in the DEBW comparable to sections $A, B$, and C.

Travelling along the Gakkel Ridge Ba:Al and Ba:Si correlations are similar to the Amundsen Basin of section $C$ (fig. 6 , tables $2 \& 3$ ). As already seen in the Amundsen DEBW of section $\mathrm{C}, \mathrm{Al}$ and Si distributions may be decoupled here from $\mathrm{Ba}$. Ba:Si data scatter close to the Nansen DEBW regression line as seen above for the Amundsen DEBW (fig. 6b).

\section{Discussion}

One of the earliest work on dissolved $\mathrm{Ba}$ in the water column of the Arctic Ocean has been part of the GEOSECS program (1972/1973) and is presented by Chan et al. (1977). Since then, many work on Ba in the upper $200 \mathrm{~m}$ of the Arctic Ocean was done but only few publications on dissolved $\mathrm{Ba}$ in the whole water column do exist (e. g. Falkner et al., 1994a). Dissolved Ba, Al and Si are correlated well in most basins but their corresponding regression lines differ between basins dependent on the sources of these elements to the Arctic Ocean (fig. 6). This allows us to identify different water masses and speculate on their sources.

\subsection{Surface waters}

Distribution of $\mathrm{Ba}$ in the SLW is highly influenced by large input of Ba-rich riverine water in combination with a strong stratification down to $150 \mathrm{~m}$ (Falkner et al., 1993; 1994b; Guay and Falkner, 1998b; Roeske et al., submitted). Below that depth we find the temperature maximum identifying the core of the incoming Atlantic water. Highest Ba concentrations are seen in the upper water column of the Makarov Basin as well as in bottom waters of the Laptev Sea shelf (figs. 3 \& 4). Because of strong stratification, Ba of the SLW is not mixed vertically but transported laterally within the upper layer and thus high concentrations do not influence lower waters except in regions of high productivity and export which are usually found on the shelves (Abrahamsen et al., 2009; Arrigo et al., 2008; Cai et al., 2010; Falkner et al., 1994b; Roeske et al., submitted).

\subsection{Nansen Basin}

The similar regression lines between $\mathrm{Ba}, \mathrm{Al}$ and $\mathrm{Si}$ in the Nansen AIDW of sections $\mathrm{A}$ to $C$ bring evidence of equivalent processes in these waters (fig. 5 , tables $2 \& 3$ ). Uptake of $\mathrm{Ba}$ in diatoms has been investigated by several authors usually together with Si and P (Collier and Edmond, 1984; Dehairs et al., 1980; Fisher et al., 1991; Ganeshram et al., 2003; Sternberg et al., 2005). The slopes of 0.33 to $0.35 \mathrm{~mol} / \mathrm{mol}$ of the Ba:Al regressions in the Nansen AIDW are in the range of data presented by Collier and Edmond (1984) for bulk plankton (0.06 to 0.55, av. 0.37) and also are in the range of 0.11 to 0.34 in zoo- and micro-plankton at Hawaii (Martin and Knauer, 1973). Regarding $\mathrm{Si}$, our Ba:Si slopes of 0.73 to $0.78 \mathrm{mmol} / \mathrm{mol}$ are in the very wide range of 0.017 to 1.4 for bulk plankton presented by Collier and Edmond (1984), too. 
We are not aware of published ratios of $\mathrm{Ba}: \mathrm{Al}$ and $\mathrm{Ba}: \mathrm{Si}$ in diatoms in the Arctic Ocean.

The Nansen AIDW of section A is influenced least by waters other than Atlantic water. The depth of the core of the Atlantic layer determined by the temperature maximum is $200 \mathrm{~m}$ here. Concentrations of $\mathrm{Ba}, \mathrm{Al}$, and $\mathrm{Si}$ at this depth are chosen as their Atlantic source concentrations. This results in an Atlantic source concentration of $42.5 \mathrm{nM} \mathrm{Ba}$, equal to the Atlantic end-member of Ba used in solving the mass balance equations to distinguish the sources of meteoric water to the Arctic Ocean on this cruise (Roeske et al., submitted). The Atlantic source concentration of Si is $5 \mu \mathrm{M}$ and that of $\mathrm{Al}$ is $4.3 \mathrm{nM}$. Ba and $\mathrm{Al}$ are depleted in the surface mixed layer (SML) of the Nansen Basin in an average $\Delta \mathrm{Ba} / \Delta \mathrm{Al}$ ratio (see eqn. 3 below) of $0.32 \mathrm{~mol} / \mathrm{mol}$. This is found by calculating

$$
\frac{\Delta B a}{\Delta A l}=\frac{B a_{a}-B a_{s}}{A l_{a}-A l_{s}}
$$

where indices a refer to the estimated concentration of the Atlantic water (see above) and indices $s$ refer to the average concentration in the SML (cf. Jeandel et al., 1996). $\Delta \mathrm{Ba} / \Delta \mathrm{Si}$ in the $\mathrm{SML}$ of the Nansen Basin is $0.25 \mathrm{mmol} / \mathrm{mol}$. While depletion of $\mathrm{Ba}$ and Al occurs at the same atomic ratio as regeneration seen in the slopes of the regression lines (table 2) this is not true for $\mathrm{Ba}$ and $\mathrm{Si}$ where the $\Delta \mathrm{Ba} / \Delta \mathrm{Si}$ ratio in the depletion is lower by about a factor 3 than the regeneration (table 3). Because Al and Si are always nearly depleted by biological production in the SML the $\Delta \mathrm{Ba} / \Delta \mathrm{Al}$ and $\Delta \mathrm{Ba} / \Delta \mathrm{Si}$ ratios strongly depend on processes removing $\mathrm{Ba}$. The same calculation on surface samples of the Barents Sea results in 1.4 to $3.4 \mathrm{~mol} / \mathrm{mol} \Delta \mathrm{Ba} / \Delta \mathrm{Al}$ and 1.1 to $2.5 \mathrm{mmol} / \mathrm{mol} \Delta \mathrm{Ba} / \Delta \mathrm{Si}$. Apparently, the higher biological productivity above the shelves (Arrigo et al., 2008) causes a deeper Ba depletion in shelf surface waters then offshore. We see that particles produced by the higher productivity on the shelves may be a source for Ba to deep waters compared with $\mathrm{Si}$ and Al. But the regression slope of $\mathrm{Ba}: \mathrm{Si}$ in the Nansen DEBW is still about twice as high as the $\Delta \mathrm{Ba} / \Delta \mathrm{Si}$ in the Barents Sea. Hence an additional source of $\mathrm{Ba}$ to the DEBW is needed. Release from resuspended sediments of the Barents Sea or particles of terrigenous origin may be this source. Moreover, because $\Delta \mathrm{Ba} / \Delta \mathrm{Al}$ on the shelf is up to ten times higher than regression slopes in the DEBW, only if particles also enhanced in Al contribute to the DEBW, we receive the observed lower slopes of the Ba:Al regression lines. This strengthens the hypothesis by Middag et al. (2009) that an additional source for $\mathrm{Al}$ to the DEBW is needed to explain Al enrichment. The dominant process is assumed to be downward convection of particles from the shelves, especially alumino silicates of terrigenous origin (Middag et al., 2009). Using a simple model Middag et al. (2009) show that if only $2 \%$ of the dissolving particles are terrigenous particles, this is sufficient to explain the higher regression slopes of $\mathrm{Al}: \mathrm{Si}$ in the Nansen DEBW.

In the Nansen DEBW of section A the slope of $\mathrm{Ba}: \mathrm{Si}$ is 3.8 times higher than in the AIDW and it is about a factor of 5.5 higher in sections $B \& C$ (fig. $5 b$, table 3 ) differing by a factor of 1.4. This is evidence of a higher regeneration of $\mathrm{Ba}$ at depth in sections $\mathrm{B} \& \mathrm{C}$. The respective data of $\mathrm{Al}$ and $\mathrm{Si}$ result in factors of 4.4 and 6 between the AIDW and DEBW of sections B and C compared with A (Middag et al., 2009), also different by a factor of $1.4 .{ }^{228} \mathrm{Ra}$ (a tracer for sediment contact) has been observed in intermediate waters down to $2000 \mathrm{~m}$ along the Barents Sea slope where it gives evidence of recent contact with slope or shelf sediments (Rutgers van der Loeff et al., 1995). Below $2600 \mathrm{~m}$ in the Nansen Basin water is renewed on a timescale of 150 to 
300 years away from the boundaries (Schlosser et al., 1995). Because of the observed Al maximum several hundreds of meters from the sediments (Middag et al., 2009) we believe it to be unlikely that this larger regeneration of $\mathrm{Ba}$ and $\mathrm{Al}$ is caused by higher diffusion of $\mathrm{Ba}$ and $\mathrm{Al}$ from the bottom sediments (Middag et al., 2009). This therefore points to influence from the Barents Sea on the deep Nansen Basin north of Severnaya Zemlya as suggested previously (Moran and Moore, 1991; Rudels et al., 2000; Rusakov et al., 2004).

At station 285 close to the Kara Sea Ba concentrations are higher compared to the following stations in the Nansen Basin (fig. 3). Ba concentrations are also higher than expected based on the regression with $\mathrm{Al}$ and $\mathrm{Si}$ (fig. 6). On a Theta-S diagram (fig. 8) we see that below $200 \mathrm{~m}$ samples at this station resemble more the lines from the Amundsen Basin. This is distinct from the Theta-S characteristics farther offshore in the Nansen Basin typical for the Fram Strait branch of the Atlantic inflow. We conclude that at station 285 we sampled waters that are not actually Nansen Basin AIDW, but actually Barents Sea-derived lower halocline water. The enhanced $\mathrm{Ba}$ concentrations in this shelf-influenced Atlantic water explain the higher $\mathrm{Ba}$ concentrations compared with $\mathrm{Al}$ and $\mathrm{Si}$ in the AIDW of the Amundsen Basin and Gakkel Ridge area (see below, figs. 3,6). Because of the deviating water mass characteristics, station 285 is not used in correlations of the Nansen Basin.

We conclude that the chemical signature of Nansen DEBW is the result of regeneration of particles with different origins: particles from the surface ocean, Ba-enriched particles from shelf production and Al-rich terrigenous particles. Because particles of the latter two sources are both transported to the DEBW by the same water mass convecting down the slope we find a good correlation between $\mathrm{Ba}, \mathrm{Al}$, and $\mathrm{Si}$. A conceptual model to visualize how we interpret the various deep water flows and processes in the Nansen Basin is presented in figure 9a. The elemental concentrations in the Nansen Basin give a consistent picture, based on circulation of Atlantic water and additional $\mathrm{Ba}, \mathrm{Al}$, and $\mathrm{Si}$ sources in the deep water that are probably derived from shelf sources. The situation gradually changes from the Nansen Basin to the Amundsen Basin to the Lomonosov Ridge and to the Makarov and Canada basins. We will use these changes to infer the different sources of intermediate and deep waters in these basins.

\subsection{Amundsen Basin and the Gakkel Ridge area}

The oldest waters on the Eurasian side of the Lomonosov Ridge are circulating in the Amundsen Basin (Jones et al., 1995). Ba:Al and Ba:Si slopes of the Amundsen AIDW are slightly lower and intercepts are higher than in the Nansen AIDW due to slightly higher concentrations of $\mathrm{Ba}$ in the Amundsen ALW towards the Lomonosov Ridge (fig. 3) while at the same time Al concentrations are lower with increasing distance from the shelf (Middag et al., 2009). This fits to circulation patterns suggested by other authors (Anderson et al., 1994; Rudels et al., 1994; Rutgers van der Loeff et al., 1995). Down to about $1200 \mathrm{~m}$ in the Amundsen Basin ${ }^{228}$ Ra was enhanced relative to the Nansen and Makarov Basins (Rutgers van der Loeff et al., 1995). This is in agreement with an explanation by Anderson et al. (1994) who showed that water is colder and fresher between 600 and $1700 \mathrm{~m}$, explaining this by a return flow of the Barents Sea branch of the lower halocline. The circulation of intermediate waters has been described by Rudels et al. (1994). As discussed above, the Ba:Al and Ba:Si ratios of station 285 from the Barents Sea branch of the lower halocline are close to 
the regression lines in the Amundsen Basin (fig. 6). This indicates inputs of the Barents Sea branch of the lower halocline to these waters.

In the Amundsen and the Gakkel DEBW Ba, Al and Si data are close to the regression line of the Nansen DEBW (fig. 6). Al:Si regressions have the same slopes as in the Nansen DEBW of section A (Middag et al., 2009) but concentrations of $\mathrm{Ba}$ and $\mathrm{Al}$ are changing from the Gakkel Ridge to the Lomonosov Ridge. While the observed Al concentrations in the Amundsen DEBW are lower at the Lomonosov Ridge than at the Gakkel Ridge the opposite is true for Ba with highest concentrations at the bottom of the Lomonosov Ridge (fig. 3). Probably a longer residence time of the DEBW close to the Lomonosov Ridge allows here a stronger scavenging removal of Al.

\subsection{Makarov Basin and the adjacent ridges}

reach this far and are then kept separated from waters of the Amundsen Basin by the boundary current. Concentrations of $\mathrm{Ba}$ in the ALW of station 319 (positioned in a trough with $2740 \mathrm{~m}$ depth) on the Lomonosov Ridge are comparable to the incoming Atlantic water in the Nansen Basin of section A while in the AIW concentrations are similar to the Amundsen AIDW (fig. 10c). We explain this distribution by a boundary current returning from the Laptev Sea slope towards the Fram Strait (Anderson et al., 1994; Rudels et al., 1994; Rudels et al., 2000) over the Lomonosov Ridge which in the ALW is composed of waters from the Nansen Basin branch of the lower halocline. Underneath that layer the Amundsen AIDW is the source to this boundary current. The Makarov Basin shows the same distribution in AIDW seen in the Lomonosov Ridge ALW (fig. 7, tables 2 to 4), indicating contribution from the Nansen Basin branch of the lower halocline to these waters. Waters at the Alpha and Mendeleyev Ridges have distributions showing influence of Canadian and Pacific waters (figs. 7, table 4). These stations are positioned farthest south on the Canadian side of the expedition's track and are most likely mixed with shelf water originated at the East Siberian Sea (Anderson et al., 1994; Jones et al., 1995). Figure 9b shows a conceptual model to visualize how we interpret the various deep water flows and processes in the Makarov Basin.

In the Makarov AIDW the Ba:Al slope is a factor of 1.5 higher compared with the Eurasian Basins AIDW (slopes are different with $p<0.01$, two-tailed t-test). While absolute concentrations of $\mathrm{Al}$ in the Makarov $\mathrm{ALW}$ reaching from the temperature maximum of the Atlantic core down to about $600 \mathrm{~m}$ are as high as in the Eurasian Basins AIDW at the same depth, concentrations are $30 \%$ lower in underlying waters. Below $800 \mathrm{~m}$ in the Makarov Basin the water becomes warmer and more saline compared with the Eurasian Basins (cf. Middag et al., 2009). Ba:Si slopes in the Makarov AIDW are close to those in the Nansen Basin (figs. $6 \mathrm{~b} \& 7 \mathrm{~b}$, tables $3 \& 4$ ) but Si concentrations in the Makarov Basin are higher by 0.5 to $2.5 \mu \mathrm{M}$ compared with the Eurasian Basins except for the AIW (cf. Middag et al., 2009). The higher concentrations of Si might be caused by waters with considerably higher concentrations in Si compared with $\mathrm{Ba}$ and $\mathrm{Al}$ entering the Makarov Basin in the depth of the ALW and below the AIDW. These waters might be of Pacific origin or from the East Siberian Sea or Canadian shelves (Falkner et al., 1994b; Guay and Falkner, 1998b; Swift et al., 1997). From the good correlations of Ba, Al, and Si in the AIDW we conclude that all three elements have the same source: Waters with concentrations higher in Si and lower in Al flowing into the Makarov Basin across the Mendeleyev Ridge (see below). 
At the Mendeleyev Ridge the Ba:Al regression line is similar to that of the Nansen AIDW (fig. 7a, table 4). The Ba:Al slopes from the data at the Alpha and Mendeleyev Ridges are not significantly different from those of the Nansen AIDW of sections $B$ and $C$ ( $p=0.17$ and $p=0.53$ respectively, two-tailed t-test). Looking at the Ba:Si data though we see a regression line totally different from all others at the Mendeleyev Ridge (fig. 7b, table 2, slopes are different with $p<0.01$ except for the Amundsen ( $p$ $=0.31$ ) and Gakkel ( $p=0.07)$ AIDW, two-tailed t-test). A slope lower by about $40 \%$ gives proof of entrainment of waters with high Si concentrations in the deep water. In fact we find high concentrations of $\mathrm{Ba}$ as well as $\mathrm{Si}$ in the deepest water of the Mendeleyev and Alpha Ridges (fig. 10a). Waters over the Alpha Ridge, being part of the Beaufort Gyre, are mixed with Pacific water as well as Canadian shelf water, raising Si concentrations another $1.5 \mu \mathrm{M}$. They either are not entering the Makarov Basin or are diluted. Si concentrations in the Mendeleyev ALW are close to those of the Makarov ALW. Below about $1000 \mathrm{~m}$ of the Alpha and Mendeleyev Ridges Si is higher by 0.9 to $1.3 \mu \mathrm{M}$ compared with the same depth of the Makarov Basin. Comparing the DMBW and DEBW (see below) we see that Si concentrations are about $1.3 \mu \mathrm{M}$ higher in the DMBW and these horizontal Si gradients show that the intermediate depth water from the Makarov Basin can not be ventilated directly from the Lomonosov Ridge. Instead, deeper waters containing a higher load in Si and entering via the Alpha and Mendeleyev Ridges could explain the higher concentrations in the deep Makarov Basin. Bottom waters of the Alpha and Mendeleyev Ridges entering the Makarov Basin and sinking to about $2500 \mathrm{~m}$ are then the source of the maximum seen in $\mathrm{Si}$ concentrations and probably $\mathrm{Ba}$, too, at this depth (figs. 9b \& 10a+b). We assume that this water mass has its origin in the boundary current AIDW that crosses the Lomonosov Ridge close to the Siberian shelf edge at 1500 to $1700 \mathrm{~m}$ depth and mixes with Siberian shelf water and Pacific water close to the Mendeleyev Ridge (Swift et al., 1997) and then enters the Makarov Basin (Rudels et al., 2000) (fig. 9b). This is in agreement with publications on Arctic circulation patterns (e.g. Jones, 2001; Jones et al., 2008; Rudels et al., 2004).

In the DMBW we see that Ba concentrations are lower by about 1 to $2 \mathrm{nM}$ compared with the DEBW (fig. 3), Al concentrations are about $5 \mathrm{nM}$ lower than in the Amundsen DEBW and even $7 \mathrm{nM}$ lower than those of the Nansen DEBW at the same depth (Middag et al., 2009). Ba and Al data of the DMBW scatter close to the regression line of the extrapolated Amundsen AIDW (fig. 6a). Si is higher by about 0.8 to $1.4 \mu \mathrm{M}$ compared with the Amundsen DEBW and has a maximum in concentration at 2500 $\mathrm{m}$ depth (Middag et al., 2009) (fig. 10b). There is no sample for Ba between $2000 \mathrm{~m}$ and $3000 \mathrm{~m}$ depth but $\mathrm{Ba}$ also shows decreasing concentrations towards the bottom of the Makarov Basin (fig. 10b). At the same time, Ba concentrations in the deepest samples over the Alpha and Mendeleyev Ridges (2000 and $2200 \mathrm{~m}$ ) are higher than at corresponding depths in the Makarov Basin (fig. 10a). We hypothesize that crossing the Mendeleyev and Alpha Ridges similar to Si a higher load of $\mathrm{Ba}$ is transported into the DMBW. We thus predict a similar maximum in $\mathrm{Ba}$ at $2500 \mathrm{~m}$ which could be confirmed by Ba measurements at the depth of the Si maximum. Bauch et al. (1995) have shown the East Siberian Sea to be an important source to the DMBW. They have shown that freshwater content in all Arctic bottom waters is about $5 \%$ but riverine water is $2 \%$ in the DMBW while it is only $1 \%$ in the DEBW. Wilson and Wallace (1990) calculated the Canadian shelf water contribution to deep water of the Canada Basin by using NO/PO ratios finding 7 to $11 \%$ and Östlund et al. (1987) found 10 to $15 \%$. Because these calculations strongly depend on uptake and mineralization of nitrate and phosphate following Redfield ratios they have to be taken with care. Ca- 
nadian Shelf water, water from the East Siberian Sea, as well as the deepest water from the Alpha and Mendeleyev Ridges is enhanced in $\mathrm{Ba}$ and $\mathrm{Si}$ and thus can not be responsible for the concentrations of $\mathrm{Ba}$ and $\mathrm{Si}$ in the $\mathrm{DMBW}$, decreasing with depth below about $2500 \mathrm{~m}$. Because the only waters with lower concentrations of $\mathrm{Ba}$, $\mathrm{Al}$, and Si are found in the Eurasian AIDW, we conclude analogous to Middag et al. (2009) that the DMBW is diluted by the Amundsen AIDW. That water crosses the Lomonosov Ridge below $2000 \mathrm{~m}$ from the Amundsen Basin in the ridge's mid-range (Jones et al., 1995) (fig. 9b) and should be sinking because it is denser than the Makarov Basin water of the same depth, thus diluting the DMBW (Jones et al., 1995; Middag et al., 2009; Timmermans et al., 2005).

\section{Conclusions}

Cycling of $\mathrm{Ba}$ in intermediate waters. The distribution of $\mathrm{Ba}, \mathrm{Al}$ and $\mathrm{Si}$ in the Nansen AIDW clearly shows the dominating influence of the Atlantic water inflow. In the Nansen AIDW north of Severnaya Zemlya the influence of lower halocline water from the Barents Sea is shown by slightly higher Ba:Al and Ba:Si ratios. The outflow of the Barents Sea branch of the lower halocline water is located here, seen in the Theta-Splot and the $\mathrm{Ba}: \mathrm{Al}$ and $\mathrm{Ba}: \mathrm{Si}$ ratios. These ratios are found again in the Amundsen and Gakkel AIDW. In the Amundsen and the Gakkel AIDW the circulation returns towards the Fram Strait (Anderson et al., 1994; Rudels et al., 1994). The Makarov AIDW shows influence of water from the East Siberian Sea and Pacific water (Anderson et al., 1994; Jones et al., 1995). In the southernmost stations on the Canadian side covered by our expedition we see waters highly enhanced in $\mathrm{Si}$, especially ALW overlying the Alpha Ridge, which is part of the Beaufort Gyre.

Cycling of $\mathrm{Ba}$ in bottom waters. The data of $\mathrm{Ba}, \mathrm{Al}$ and $\mathrm{Si}$ clearly show dissolution processes of shelf-derived particles in the sampled deep waters. This is especially obvious north of Severnaya Zemlya where higher Ba:Si and Al:Si regression slopes point to particle-loaded dense water from the Barents Sea convecting downwards into the DEBW (Moran and Moore, 1991; Rudels et al., 2000). The location of this convection is given by Rudels et al. (2000) and cannot be distinguished from our elemental ratios. Clearly, dissolution of particles sinking from surface water and derived from the shelves both contribute to the enrichment of $\mathrm{Ba}$ in deep waters observed in the model of Taylor et al. (2003). On the other hand, correlations between $\mathrm{Ba}$ and silicate suggest that $\mathrm{Ba}$ has to be seen as a semi-conservative tracer at best. Furthermore our results support the hypothesis by Middag et al. (2009) following Jones et al. (1995) that Eurasian AIDW flows over the Lomonosov Ridge below 2000 $m$ depth into the deep Makarov Basin, where it sinks under Si- and Ba-richer water masses of Pacific origin with a Si and probably Ba maximum at approximately 2500 $\mathrm{m}$.

\section{Acknowledgements}

This work has been funded by the EU Sixth Framework Programme DAMOCLES (Developing Arctic Modelling and Observing Capabilities for Long-term Environment Studies), contract number 018509GOCE.

We thank captain and crew of Polarstern and chief scientist Ursula Schauer for their help during the expedition ARK-XXII/2. We are grateful for the hydrographic teams of $\mathrm{AWI}$ and NIOZ for supplying us water samples and hydrographic data. Also the good support by people from the IPY (International Polar Year) and the GEOTRACES pro- 
gram (international study of the global marine biogeochemical cycles of trace elements and their isotopes) has to be emphasized. Special thanks go to Sabine Mertineit who collected the Ba samples during Polarstern cruise ARK-XXII/2. Moreover we have to thank Prof. Hein De Baar from the NIOZ who made possible the access to their archived samples as well as Maarten Klunder and Patrick Laan from the NIOZ for their cooperative help.

\section{References}

Aagaard, K. and Carmack, E.C., 1989. The Role of Sea Ice and Other Fresh-Water in the Arctic Circulation. Journal of Geophysical Research C: Oceans, 94(C10): 14485-14498, doi:10.1029/JC094iC10p14485.

Aagaard, K., Coachman, L.K., Carmack, E., 1981. On the Halocline of the Arctic Ocean. Deep-Sea Research Part I: Oceanographic Research Papers, 28(6): 529-545, doi:10.1016/0198-0149(81)90115-1.

Abrahamsen, E.P., Meredith, M.P., Falkner, K.K., Torres-Valdes, S., Leng, M.J., Alkire, M.B., Bacon, S., Laxon, S.W., Polyakov, I., Ivanov, V., 2009. Tracerderived freshwater composition of the Siberian continental shelf and slope following the extreme Arctic summer of 2007. Geophysical Research Letters, 36 : 5 pp., doi:10.1029/2009gl037341.

Anderson, L.G., Björk, G., Holby, O., Jones, E.P., Kattner, G., Koltermann, K.P., Liljeblad, B., Lindegren, R., Rudels, B., Swift, J., 1994. Water Masses and Circulation in the Eurasian Basin - Results From the Oden 91 Expedition. Journal of Geophysical Research C: Oceans, 99(C2): 3273-3283.

Arrigo, K.R., van Dijken, G., Pabi, S., 2008. Impact of a shrinking Arctic ice cover on marine primary production. Geophysical Research Letters, 35(L19603): 6 pp., doi:10.1029/2008GL035028.

Bauch, D., Schlosser, P., Fairbanks, R.G., 1995. Fresh-Water Balance and the Sources of Deep and Bottom Waters in the Arctic-Ocean Inferred from the Distribution of $\mathrm{H}_{2}{ }^{18} \mathrm{O}$. Progress in Oceanography, 35(1): 53-80, doi:10.1016/0079-6611(95)00005-2.

Broecker, W.S., 1974. "NO", a Conservative Water-Mass Tracer. Earth and Planetary Science Letters, 23(1): 100-107, doi:10.1016/0012-821X(74)90036-3.

Cai, P., Rutgers van der Loeff, M., Stimac, I., Nöthig, E.-M., Lepore, K., Moran, S.B., 2010. Low export flux of particulate organic carbon in the central Arctic Ocean as revealed by ${ }^{234} \mathrm{Th}:{ }^{238} \mathrm{U}$ disequilibrium. Journal of Geophysical Research C: Oceans, doi:10.1029/2009JC005595.

Chan, L.H., Drummond, D., Edmond, J.M., Grant, B., 1977. On the barium data from the Atlantic GEOSECS expedition. Deep Sea Research, 24(7): 613-649, doi:10.1016/0146-6291(77)90505-7.

Collier, R. and Edmond, J., 1984. The trace element geochemistry of marine biogenic particulate matter. Progress In Oceanography, 13(2): 113-199, doi:10.1016/0079-6611(84)90008-9.

De Baar, H.J.W., Timmermans, K.R., Laan, P., De Porto, H.H., Ober, S., Blom, J.J., Bakker, M.C., Schilling, J., Sarthou, G., Smit, M.G., Klunder, M., 2008. Titan: A new facility for ultraclean sampling of trace elements and isotopes in the deep oceans in the international Geotraces program. Marine Chemistry, 111(1-2): 4-21, doi:10.1016/j.marchem.2007.07.009.

Dehairs, F., Chesselet, R., Jedwab, J., 1980. Discrete suspended particles of barite and the barium cycle in the open ocean. Earth and Planetary Science Letters, 49(2): 528-550, doi:10.1016/0012-821X(80)90094-1. 
Dickson, R., Rudels, B., Dye, S., Karcher, M., Meincke, J., Yashayaev, I., 2007. Current estimates of freshwater flux through Arctic and subarctic seas. Progress in Oceanography, 73(3-4): 210-230, doi:10.1016/j.pocean.2006.12.003.

Falkner, K.K., Klinkhammer, G.P., Bowers, T.S., Todd, J.F., Lewis, B.L., Landing, W.M., Edmond, J.M., 1993. The behavior of barium in anoxic marine waters. Geochimica et Cosmochimica Acta, 57(3): 537-554, doi:10.1016/00167037(93)90366-5.

Falkner, K.K., Macdonald, R.W., Carmack, E.C., Weingartner, T., 1994a. Barium in seawater and sediments from the Artic Ocean. http://doi.pangaea.de/10.1594/PANGAEA.734072, latest access on March 30, 2011.

Falkner, K.K., MacDonald, R.W., Carmack, E.C., Weingartner, T., 1994b. The potential of barium as a tracer of Arctic water masses. In: O.M. Johannessen, R.D. Muench and J.E. Overland (Editors), The Polar Oceans and Their Role in Shaping the Global Environment: The Nansen Centennial Volume, AGU Geophysics Monograph Series. American Geophysical Union, Washington, DC, pp. 63-76.

Fisher, N.S., Guillard, R.R.L., Bankston, D.C., 1991. The Accumulation of Barium by Marine-Phytoplankton Grown in Culture. Journal of Marine Research, 49(2): 339-354, doi:10.1357/002224091784995882.

Freydier, R., Dupré, B., Polve, M., 1995. Analyses by Inductively-Coupled PlasmaMass Spectrometry of Ba Concentrations in Water and Rock Samples - Comparison between Isotope-Dilution and External Calibration with or without Internal Standard. European Mass Spectrometry, 1(3): 283-291.

Ganeshram, R.S., François, R., Commeau, J., Brown-Leger, S.L., 2003. An experimental investigation of barite formation in seawater. Geochimica et Cosmochimica Acta, 67(14): 2599-2605, doi:10.1016/S0016-7037(03)00164-9.

Grasshoff, K., Erhardt, M., Kremling, K., 1983. Methods of seawater analysis. Verlag Chemie, Weinheim, Germany, 419 pp.

Guay, C.K. and Falkner, K.K., 1998a. A survey of dissolved barium in the estuaries of major Arctic rivers and adjacent seas. Continental Shelf Research, 18(8): 859882, doi:10.1016/S0278-4343(98)00023-5.

Guay, C.K. and Falkner, K.K., 1998b. Barium as a tracer of Arctic halocline and river waters. Deep-Sea Research Part II: Topical Studies in Oceanography, 44(8): 1543-1569, doi:10.1016/S0967-0645(97)00066-0.

Guay, C.K.H., McLaughlin, F.A., Yamamoto-Kawai, M., 2009. Differentiating fluvial components of upper Canada Basin waters on the basis of measurements of dissolved barium combined with other physical and chemical tracers. Journal of Geophysical Research, 114(C00A09): 16 pp., doi:10.1029/2008JC005099.

Jeandel, C., Dupré, B., Lebaron, G., Monnin, C., Minster, J.F., 1996. Longitudinal distributions of dissolved barium, silica and alkalinity in the western and southern Indian Ocean. Deep Sea Research Part I: Oceanographic Research Papers, 43(1): 1-31, doi:10.1016/0967-0637(95)00098-4.

Jones, E.P., 2001. Circulation in the Arctic Ocean. Polar Research, 20(2): 139-146. Jones, E.P. and Anderson, L.G., 1986. On the Origin of the Chemical Properties of the Arctic Ocean Halocline. Journal of Geophysical Research C: Oceans, 91(C9): 10759-10767, doi:10.1029/JC091iC09p10759.

Jones, E.P., Anderson, L.G., Jutterstrom, S., Mintrop, L., Swift, J.H., 2008. Pacific freshwater, river water and sea ice meltwater across Arctic Ocean basins: Results from the 2005 Beringia Expedition. Journal of Geophysical Research C: Oceans, 113(C08012): 10 pp., doi:10.1029/2007jc004124. 
Jones, E.P., Anderson, L.G., Wallace, D.W.R., 1991. Tracers of near-surface, halocline and deep waters in the Arctic ocean: Implications for circulation. Journal of Marine Systems, 2(1-2): 241-255, doi:10.1016/0924-7963(91)90027-R.

Jones, E.P., Rudels, B., Anderson, L.G., 1995. Deep waters of the Arctic Ocean: origins and circulation. Deep Sea Research Part I: Oceanographic Research Papers, 42(5): 737-760, doi:10.1016/0967-0637(95)00013-V.

Kinney, M.E.A. and Burrell, C.C., 1970. Chemical characteristics of water masses in the Amerasian Basin of the Arctic Ocean. Journal of Geophysical Research C: Oceans, 75(21): 137-158, doi:10.1029/JC075i021p04097.

Klinkhammer, G.P. and Chan, L.H., 1990. Determination of barium in marine waters by isotope dilution inductively coupled plasma mass spectrometry. Analytica Chimica Acta, 232: 323-329, doi:10.1016/S0003-2670(00)81249-0.

Martin, J.H. and Knauer, G.A., 1973. The elemental composition of plankton. Geochimica et Cosmochimica Acta, 37(7): 1639-1653, doi:10.1016/00167037(73)90154-3.

Middag, R., de Baar, H.J.W., Laan, P., Bakker, K., 2009. Dissolved aluminium and the silicon cycle in the Arctic Ocean. Marine Chemistry, 115(3-4): 176-195, doi:10.1016/j.marchem.2009.08.002.

Moore, R.M., Lowings, M.G., Tan, F.C., 1983. Geochemical Profiles in the Central Arctic Ocean: Their Relation to Freezing and Shallow Circulation. Journal of Geophysical Research, 88(C4): 2667-2674, doi:10.1029/JC088iC04p02667.

Moore, W.S. and Dymond, J., 1991. Fluxes of ${ }^{226} \mathrm{Ra}$ and barium in the Pacific Ocean: The importance of boundary processes. Earth and Planetary Science Letters, 107(1): 55-68, doi:10.1016/0012-821X(91)90043-H.

Moore, W.S. and Shaw, T.J., 2008. Fluxes and behavior of radium isotopes, barium, and uranium in seven Southeastern US rivers and estuaries. Marine Chemistry, 108(3-4): 236-254, doi:10.1016/j.marchem.2007.03.004.

Moran, S.B. and Moore, R.M., 1991. The Potential Source of Dissolved Aluminium From Resuspended Sediments to the North Atlantic Deep Water. Geochimica Et Cosmochimica Acta, 55(10): 2745-2751, doi:10.1016/0016-7037(91)904417.

Morison, J., Steele, M., Andersen, R., 1998. Hydrography of the upper Arctic Ocean measured from the nuclear submarine USS Pargo. Deep-Sea Research Part I-Oceanographic Research Papers, 45(1): 15-38, doi:10.1016/S09670637(97)00025-3.

Östlund, H.G., Possnert, G., Swift, J.H., 1987. Ventilation Rate of the Deep Arctic Ocean From Carbon 14 Data. Journal Geophysical Research C: Oceans, 92(C4): 3769-3777, doi:10.1029/JC092iC04p03769.

Rabe, B., Schauer, U., Mackensen, A., Karcher, M., Hansen, E., BeszczynskaMöller, A., 2009. Freshwater components and transports in the Fram Strait recent observations and changes since the late 1990s. Ocean Science, 5(3): 219-233, doi:10.5194/osd-6-581-2009.

Rabe, B., Karcher, M., Schauer, U., Toole, J. M., Krishfield, R. A., Pisarev, S., Kauker, F., Gerdes, R., Kikuchi, T., 2011. An assessment of Arctic Ocean freshwater content changes from the 1990s to the 2006-2008 period. Deep Sea Research Part I: Oceanographic Research Papers, 58: 173-185, doi:10.1016/j.dsr.2010.12.002.

Resing, J.A. and Measures, C.I., 1994. Fluorometric-Determination of Al in Seawater by Flow-Injection Analysis With In-Line Preconcentration. Analytical Chemistry, 66(22): 4105-4111, doi:10.1021/ac00094a039. 
Roeske, T., Rutgers van der Loeff, M.M., Bauch, D., 2011. Barium measured on water bottle samples during POLARSTERN cruise ARK-XXII/2 (SPACE). http://doi.pangaea.de/10.1594/PANGAEA.758745.

Roeske, T., Bauch, D., Rutgers van der Loeff, M. M., submitted to Marine Chemistry. Utility of dissolved $\mathrm{Ba}$ in distinguishing North American from Eurasian runoff in the Arctic Ocean.

Rudels, B., Jones, E.P., Anderson, L.G., Kattner, G., 1994. On the intermediate depth waters of the Arctic Ocean. In: O.M. Johannessen, R.D. Muench and J.E. Overland (Editors), The Polar Oceans and their role in shaping the global environment. AGU Geophysical Monograph, 85, pp. 33-46.

Rudels, B., Jones, E.P., Schauer, U., Eriksson, P., 2004. Atlantic sources of the Arctic Ocean surface and halocline waters. Polar Research, 23(2): 181-208, Doi:10.1111/j.1751-8369.2004.tb00007.x.

Rudels, B., Muench, R.D., Gunn, J., Schauer, U., Friedrich, H.J., 2000. Evolution of the Arctic Ocean boundary current north of the Siberian shelves. Journal of Marine Systems, 25(1): 77-99, doi:10.1016/S0924-7963(00)00009-9.

Rusakov, V.Y. et al., 2004. Distribution and mineral composition of particulate matter in the Franz Victoria Trough (northern Barents Sea). Oceanology, 44(2): 247256.

Rutgers van der Loeff, M. et al., 2003. ${ }^{228} \mathrm{Ra}$ and ${ }^{226} \mathrm{Ra}$ in the Kara and Laptev seas. Continental Shelf Research, 23(1): 113-124, doi:10.1016/S02784343(02)00169-3.

Rutgers van der Loeff, M.M., Key, R.M., Scholten, J., Bauch, D., Michel, A., 1995. ${ }^{228} \mathrm{Ra}$ as a tracer for shelf water in the arctic ocean. Deep Sea Research Part II: Topical Studies in Oceanography, 42(6): 1533-1553, doi:10.1016/09670645(95)00053-4.

Schauer, U., 2008. The expedition ARKTIS-XXII/2 of the research vessel "Polarstern" in 2007. Berichte zur Polar- und Meeresforschung $=$ Reports on polar and marine research(579): $271 \mathrm{pp}$.

Schlitzer, R., 2010. Ocean Data View, http://odv.awi.de, latest access on March 30, 2011.

Schlosser, P., Bönisch, G., Kromer, B., Loosli, H.H., Bühler, R., Bayer, R., Bonani, G., Koltermann, K.P., 1995. Mid-1980s distribution of tritium, ${ }^{3} \mathrm{He},{ }^{14} \mathrm{C}$ and ${ }^{39} \mathrm{Ar}$ in the Greenland/Norwegian Seas and the Nansen Basin of the Arctic Ocean. Progress In Oceanography, 35(1): 1-28, doi:10.1016/0079-6611(95)00003-Y.

Serreze, M.C., Barrett, A.P., Slater, A.G., Woodgate, R.A., Aagaard, K., Lammers, R.B., Steele, M., Moritz, R., Meredith, M., Lee, C. M., 2006. The large-scale freshwater cycle of the Arctic. Journal of Geophysical Research C: Oceans, 111(C11010): 19 pp., doi:10.1029/2005JC003424.

Steele, M. and Boyd, T., 1998. Retreat of the cold halocline layer in the Arctic Ocean. Journal of Geophysical Research C: Oceans, 103(C5): 10419-10435, doi:10.1029/98JC00580.

Sternberg, E., Tang, D., Ho, T.Y., Jeandel, C., Morel, F.M.M., 2005. Barium uptake and adsorption in diatoms. Geochimica et Cosmochimica Acta, 69(11): 27452752, doi:10.1016/j.gca.2004.11.026.

Swift, J.H. et al., 1997. Waters of the Makarov and Canada basins. Deep Sea Research Part II: Topical Studies in Oceanography, 44(8): 1503-1529, doi:10.1016/S0967-0645(97)00055-6.

Taylor, J.R., Falkner, K.K., Schauer, U., Meredith, M., 2003. Quantitative considerations of dissolved barium as a tracer in the Arctic Ocean. Journal of Geophysical Research C: Oceans, 108(3374), 13 pp., doi:10.1029/2002JC001635. 
Timmermans, M.L., Winsor, P., Whitehead, J.A., 2005. Deep-Water Flow over the Lomonosov Ridge in the Arctic Ocean. Journal of Physical Oceanography, 35(8): 1489-1493, doi:10.1175/JPO2765.1.

Weingartner, T.J., Cavalieri, D.J., Aagaard, K., Sasaki, Y., 1998. Circulation, dense water formation, and outflow on the northeast Chukchi shelf. Journal of Geophysical Research C: Oceans, 103(C4): 7647-7661.

Wilson, C. and Wallace, D.W.R., 1990. Using the Nutrient Ratio NO/PO as a Tracer of Continental Shelf Waters in the Central Arctic Ocean. Journal of Geophysical Research, 95(C12): 22193-22208.

Yamamoto-Kawai, M., McLaughlin, F.A., Carmack, E.C., Nishino, S., Shimada, K., 2008. Freshwater budget of the Canada Basin, Arctic Ocean, from salinity, $\delta^{18} \mathrm{O}$, and nutrients. Journal of Geophysical Research C: Oceans, 113(C01007): 12 pp., doi:10.1029/2006JC003858.

Table 1: Station positions on ARK-XXII/2 in degrees latitude and longitude (first position of the station log).

\begin{tabular}{|c|c|c|c|c|c|c|c|}
\hline Section & Station & Lat. ${ }^{\circ} \mathrm{N}$ & Lon. ${ }^{\circ} \mathrm{E}$ & Section & Station & Lat. ${ }^{\circ} \mathrm{N}$ & Lon. ${ }^{\circ} \mathrm{E}$ \\
\hline \multirow[t]{8}{*}{$\bar{A}$} & 228 & $75^{\circ} 0.03^{\prime}$ & $33^{\circ} 59.95^{\prime}$ & \multirow[t]{11}{*}{ C } & 306 & $85^{\circ} 55.37^{\prime}$ & $91^{\circ} 7.26^{\prime}$ \\
\hline & 236 & $77^{\circ} 30.04^{\prime}$ & $33^{\circ} 59.79^{\prime}$ & & 309 & $87^{\circ} 2.74^{\prime}$ & $104^{\circ} 47.21^{\prime}$ \\
\hline & 237 & $78^{\circ} 59.83^{\prime}$ & $33^{\circ} 59.68^{\prime}$ & & 310 & $87^{\circ} 39.46^{\prime}$ & $112^{\circ} 2.23^{\prime}$ \\
\hline & 239 & $80^{\circ} 59.69^{\prime}$ & $33^{\circ} 59.76^{\prime}$ & & 316 & $88^{\circ} 10.58^{\prime}$ & $139^{\circ} 37.07^{\prime}$ \\
\hline & 246 & $81^{\circ} 52.10^{\prime}$ & $34^{\circ} 0.72^{\prime}$ & & 319 & $88^{\circ} 39.86^{\prime}$ & $153^{\circ} 39.66^{\prime}$ \\
\hline & 255 & $82^{\circ} 30.20^{\prime}$ & $33^{\circ} 57.12^{\prime}$ & & 326 & $88^{\circ} 1.71^{\prime}$ & $170^{\circ} 5.23^{\prime}$ \\
\hline & 258 & $83^{\circ} 59.93^{\prime}$ & $34^{\circ} 0.62^{\prime}$ & & 328 & $87^{\circ} 49.80^{\prime}$ & $-170^{\circ} 34.10^{\prime}$ \\
\hline & 260 & $84^{\circ} 29.36^{\prime}$ & $36^{\circ} 8.31^{\prime}$ & & 333 & $87^{\circ} 1.68^{\prime}$ & $-146^{\circ} 23.98^{\prime}$ \\
\hline \multirow[t]{5}{*}{$B$} & 261 & $84^{\circ} 38.72^{\prime}$ & $60^{\circ} 56.02^{\prime}$ & & 338 & $85^{\circ} 42.25^{\prime}$ & $-135^{\circ} 2.35^{\prime}$ \\
\hline & 266 & $83^{\circ} 8.27^{\prime}$ & $61^{\circ} 44.46^{\prime}$ & & 342 & $84^{\circ} 30.00^{\prime}$ & $-138^{\circ} 25.12^{\prime}$ \\
\hline & 271 & $82^{\circ} 30.18^{\prime}$ & $60^{\circ} 47.71^{\prime}$ & & 349 & $85^{\circ} 3.83^{\prime}$ & $-164^{\circ} 28.14^{\prime}$ \\
\hline & 272 & $82^{\circ} 15.12^{\prime}$ & $61^{\circ} 59.76^{\prime}$ & \multirow[t]{9}{*}{$\mathrm{D}$} & 371 & $84^{\circ} 39.19^{\prime}$ & $102^{\circ} 44.18^{\prime}$ \\
\hline & 276 & $82^{\circ} 5.05^{\prime}$ & $68^{\circ} 57.50^{\prime}$ & & 373 & $84^{\circ} 11.93^{\prime}$ & $108^{\circ} 56.10^{\prime}$ \\
\hline \multirow[t]{7}{*}{ C } & 279 & $81^{\circ} 14.71^{\prime}$ & $86^{\circ} 12.13^{\prime}$ & & 379 & $82^{\circ} 51.93^{\prime}$ & $117^{\circ} 49.73^{\prime}$ \\
\hline & 285 & $82^{\circ} 8.51^{\prime}$ & $86^{\circ} 19.75^{\prime}$ & & 382 & $81^{\circ} 21.45^{\prime}$ & $120^{\circ} 43.12^{\prime}$ \\
\hline & 291 & $82^{\circ} 42.61^{\prime}$ & $86^{\circ} 15.92^{\prime}$ & & 385 & $79^{\circ} 21.14^{\prime}$ & $124^{\circ} 21.63^{\prime}$ \\
\hline & 295 & $83^{\circ} 16.33^{\prime}$ & $86^{\circ} 16.97^{\prime}$ & & 389 & $78^{\circ} 21.30^{\prime}$ & $124^{\circ} 30.89^{\prime}$ \\
\hline & 299 & $84^{\circ} 3.06^{\prime}$ & $89^{\circ} 2.53^{\prime}$ & & 400 & $77^{\circ} 23.29^{\prime}$ & $123^{\circ} 24.02^{\prime}$ \\
\hline & 301 & $84^{\circ} 34.81^{\prime}$ & $89^{\circ} 50.14^{\prime}$ & & 407 & $76^{\circ} 10.83^{\prime}$ & $122^{\circ} 7.72^{\prime}$ \\
\hline & 302 & $84^{\circ} 53.56^{\prime}$ & $90^{\circ} 3.27^{\prime}$ & & 411 & $75^{\circ} 12.00^{\prime}$ & $121^{\circ} 21.45^{\prime}$ \\
\hline
\end{tabular}

Table 2: Regression lines of Ba vs. Al. Numbers in brackets are the error of the $95 \%$ confidence level of the intercept and slope respectively.

\begin{tabular}{|c|c|c|c|c|}
\hline $\begin{array}{l}\text { Ba vs. } \mathrm{Al} \\
\mathrm{Ba}=\end{array}$ & Nansen & Amundsen & Gakkel & Makarov \\
\hline $\begin{array}{l}\text { Section A } \\
\text { Section B }\end{array}$ & $\begin{array}{l}\text { AIDW } \\
\mathbf{4 1 . 1}+\mathbf{0} . \mathbf{3 5} \cdot \mathbf{A I} \\
( \pm 0.4,0.05) \\
\mathrm{R}^{2}=0.91, \mathrm{n}=24 \\
\mathbf{4 1 . 6}+\mathbf{0} \cdot \mathbf{3 3} \cdot \mathrm{Al} \\
( \pm 0.6,0.05) \\
\mathrm{R}^{2}=0.97, \mathrm{n}=9\end{array}$ & & & \\
\hline
\end{tabular}




\begin{tabular}{|c|c|c|c|c|}
\hline $\begin{array}{l}\text { Section C } \\
\text { Section D }\end{array}$ & $\begin{array}{l}41.7+0.33 \cdot A l \\
( \pm 0.6,0.05) \\
R^{2}=0.87, n=26\end{array}$ & $\begin{array}{l}43.0+0.30 \cdot A \mathbf{I} \\
( \pm 0.9,0.09) \\
R^{2}=0.86, n=9\end{array}$ & $\begin{array}{l}\mathbf{4 2 . 4}+\mathbf{0 . 3 2} \cdot \mathbf{A l} \\
( \pm 0.4,0.04) \\
\mathrm{R}^{2}=0.91, \mathrm{n}=24\end{array}$ & 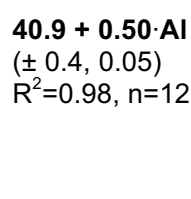 \\
\hline $\begin{array}{l}\text { Section A } \\
\text { Section B } \\
\text { Section C }\end{array}$ & $\begin{array}{l}\text { DEBW } \\
\mathbf{4 2 . 3 + 0 . 2 8 \cdot A l} \\
( \pm 1.3,0.06) \\
R^{2}=0.89, n=13 \\
42.8+0.25 \cdot A l \\
( \pm 2.7,0.11) \\
R^{2}=0.86, n=5 \\
\mathbf{4 2 . 4 + 0 . 2 8 \cdot A l} \\
( \pm 1.4,0.06) \\
R^{2}=0.96, n=6\end{array}$ & & & \\
\hline
\end{tabular}

Table 3: Regression lines of Ba vs. Si. Numbers in brackets are the error of the $95 \%$ confidence level of the intercept and slope respectively.

\begin{tabular}{|c|c|c|c|c|}
\hline $\begin{array}{l}\text { Ba vs. Si } \\
\mathrm{Ba} \cdot 10^{3}=\end{array}$ & Nansen & Amundsen & Gakkel & Makarov \\
\hline $\begin{array}{l}\text { Section A } \\
\text { Section B } \\
\text { Section C } \\
\text { Section D }\end{array}$ & 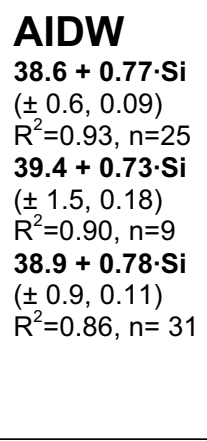 & $\begin{array}{l}\mathbf{4 0 . 2 + 0 . 7 1 \cdot S i} \\
( \pm 2.1,0.26) \\
R^{2}=0.77, n=11\end{array}$ & $\begin{array}{l}39.8+0.70 \cdot \mathbf{S i} \\
( \pm 0.8,0.1) \\
R^{2}=0.87, n=29\end{array}$ & $\begin{array}{l}37.5+0.85 \cdot \mathbf{S i} \\
( \pm 0.9,0.11) \\
R^{2}=0.96, n=12\end{array}$ \\
\hline $\begin{array}{l}\text { Section A } \\
\text { Section B } \\
\text { Section C }\end{array}$ & $\begin{array}{l}\text { DEBW \& } \\
15.2+2.95 \cdot \mathbf{S i} \\
( \pm 8,0.7) \\
\mathrm{R}^{2}=0.85, \mathrm{n}=14 \\
\mathbf{3 . 3}+\mathbf{4} . \mathbf{0 3} \cdot \mathbf{S i} \\
( \pm 15.6,1.4) \\
\mathrm{R}^{2}=0.92, \mathrm{n}=5 \\
\mathbf{1 . 8}+\mathbf{4 . 2} \cdot \mathbf{S i} \\
( \pm 15.6,1.4) \\
\text { Robustfit, } \mathrm{n}=6\end{array}$ & & & $\begin{array}{l}\mathbf{1 4 . 4}+\mathbf{2 . 7 8} \cdot \mathbf{S i} \\
( \pm 20,1.6) \\
\mathrm{R}^{2}=0.77, \mathrm{n}=8\end{array}$ \\
\hline
\end{tabular}

Table 4: Regression lines of $\mathrm{Ba}$ vs. Al and $\mathrm{Si}$ on the Canadian side of the Lomonosov Ridge. Numbers in brackets are the error of the $95 \%$ confidence level of the intercept and slope respectively.

\begin{tabular}{|c|c|c|c|c|}
\hline Canadian AIDW & Lomonosov & Makarov & Alpha & Mendeleyev \\
\hline $\begin{array}{l}\mathrm{Ba}= \\
\text { Section C }\end{array}$ & $\begin{array}{l}\text { Ba vs. Al } \\
\text { 40.8 + 0.48.Al } \\
( \pm 0.7,0.07) \\
\mathrm{R}^{2}=0.97, \mathrm{n}=8\end{array}$ & $\begin{array}{l}\mathbf{4 0 . 9}+\mathbf{0 . 5 0} \cdot \mathbf{A l} \\
( \pm 0.4,0.05) \\
\mathrm{R}^{2}=0.98, \mathrm{n}=12\end{array}$ & $\begin{array}{l}\mathbf{4 1 . 1}+\mathbf{0 . 4 0} \cdot \mathbf{A l} \\
( \pm 0.7,0.09) \\
\mathrm{R}^{2}=0.94, \mathrm{n}=7\end{array}$ & $\begin{array}{l}\begin{array}{l}\mathbf{4 1 . 2}+\mathbf{0 . 3 7} \cdot \mathbf{A l} \\
( \pm 0.7,0.12) \\
\mathrm{R}^{2}=0.95, n=4\end{array}\end{array}$ \\
\hline $\begin{array}{l}\mathrm{Ba} \cdot 10^{3}= \\
\text { Section C }\end{array}$ & $\begin{array}{l}\text { Ba vS. Si } \\
37.1+0.99 \cdot \mathbf{S i} \\
( \pm 1.9,0.24) \\
\mathrm{R}^{2}=0.88, \mathrm{n}=11\end{array}$ & $\begin{array}{l}37.5+0.85 \cdot \mathbf{S i} \\
( \pm 0.9,0.11) \\
R^{2}=0.96, n=12\end{array}$ & $\begin{array}{l}36.2+0.92 \cdot \mathbf{S i} \\
( \pm 1.6,0.18) \\
R^{2}=0.95, n=7\end{array}$ & $\begin{array}{l}\mathbf{3 9 . 3}+\mathbf{0 . 5 6} \cdot \mathbf{S i} \\
( \pm 0.9,0.11) \\
\mathrm{R}^{2}=0.97, n=5\end{array}$ \\
\hline
\end{tabular}




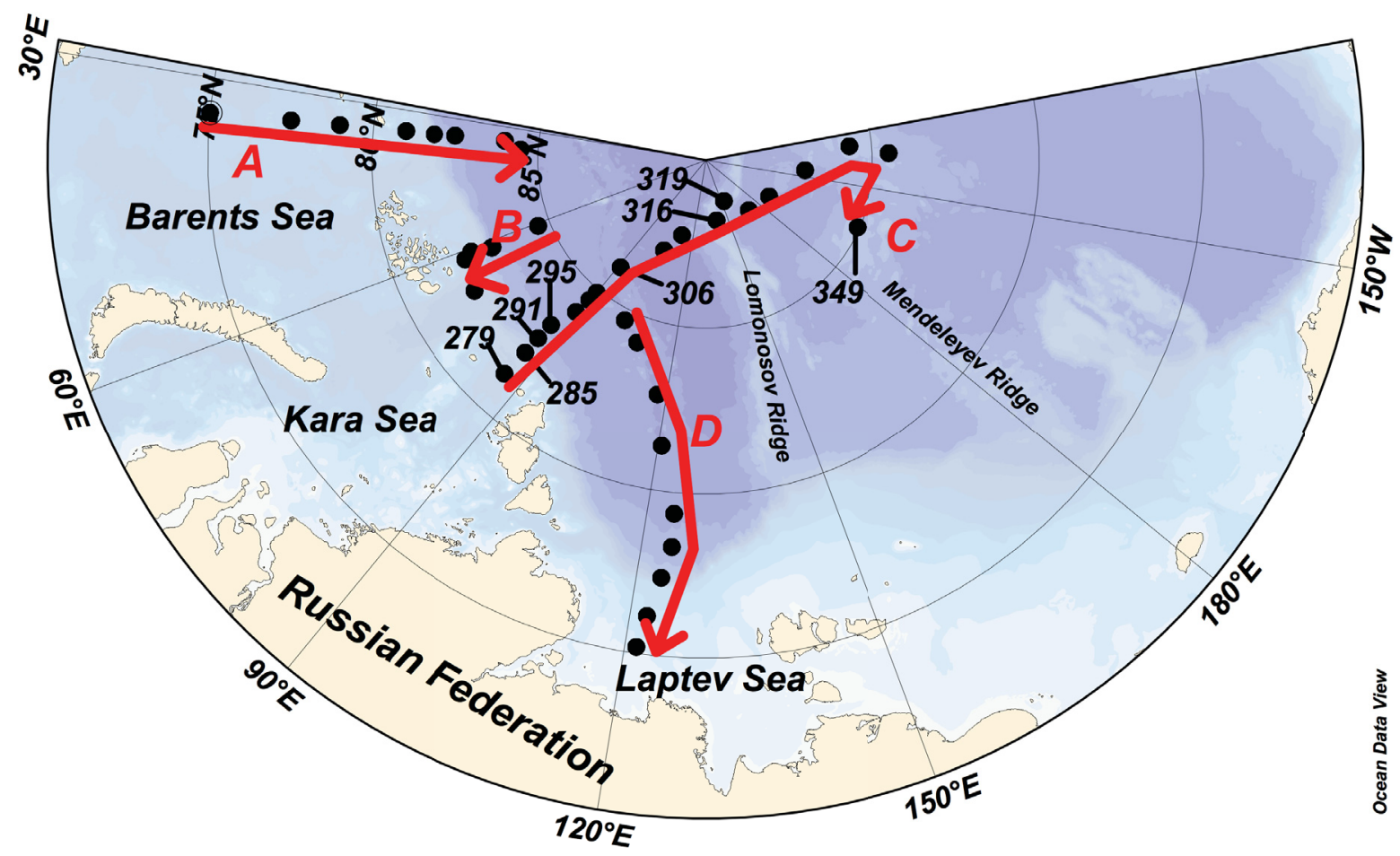

Fig. 1: Transects at Polarstern expedition ARK-XXII/2 from July to October 2007.

Sections are following the cruise track. The station numbers and their respective coordinates are shown in table 1. Station 285 is positioned on the slope of the Kara Sea. Station 319 is positioned in a trough of the Lomonosov Ridge. Station 349 on the Mendeleyev Ridge is discussed together with section $C$.

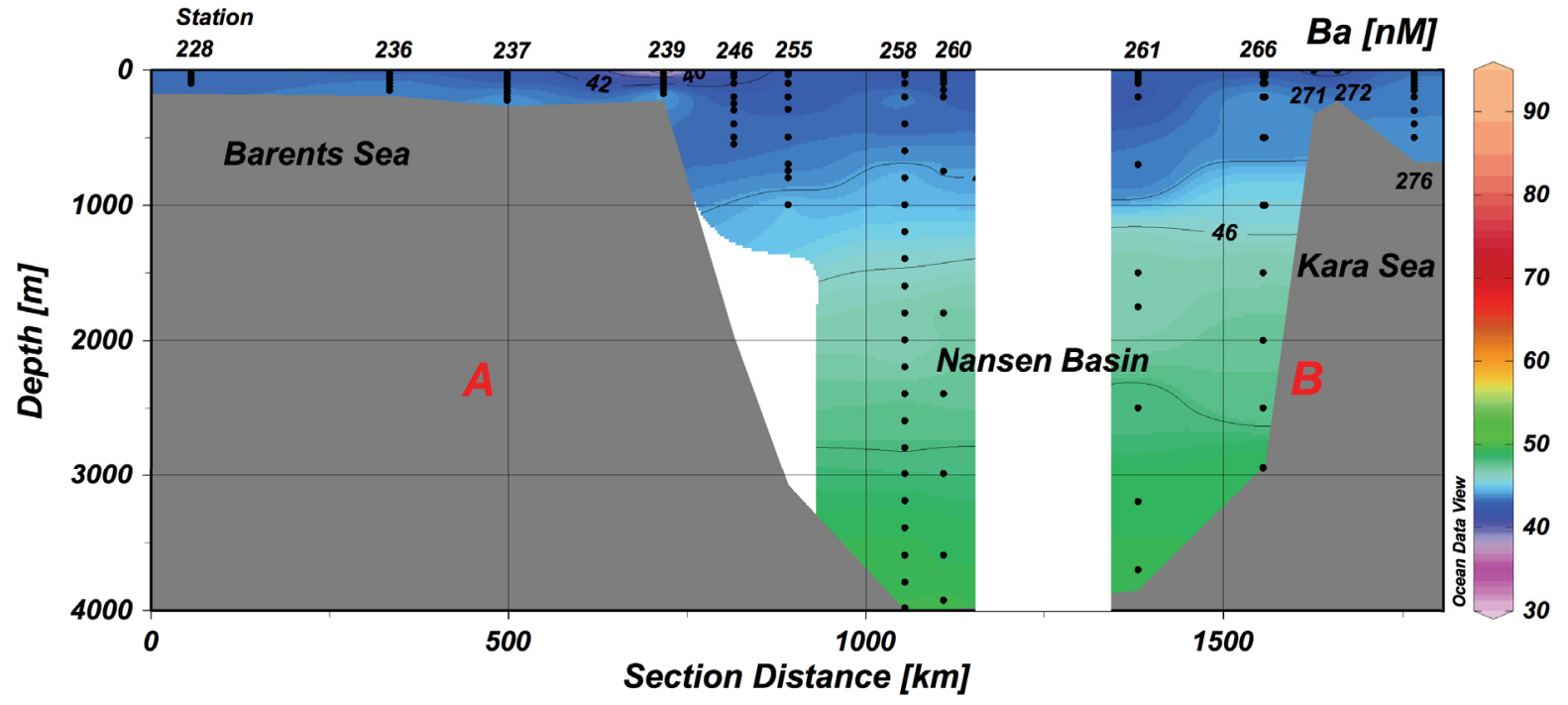

Fig. 2: Distribution of $B a$ on sections $A$ and $B$. Section A includes stations 228 to 260 and reaches from the Barents Sea at $75^{\circ} \mathrm{N}$ to the Nansen Basin at $84.49^{\circ} \mathrm{N}$. Section $\mathrm{B}$ includes stations 261 to 276 and reaches from the Nansen Basin at $84.65^{\circ} \mathrm{N}$ to the Kara Sea at $82.08^{\circ} \mathrm{N}$. Isolines are at $2 \mathrm{nM}$ intervals. 


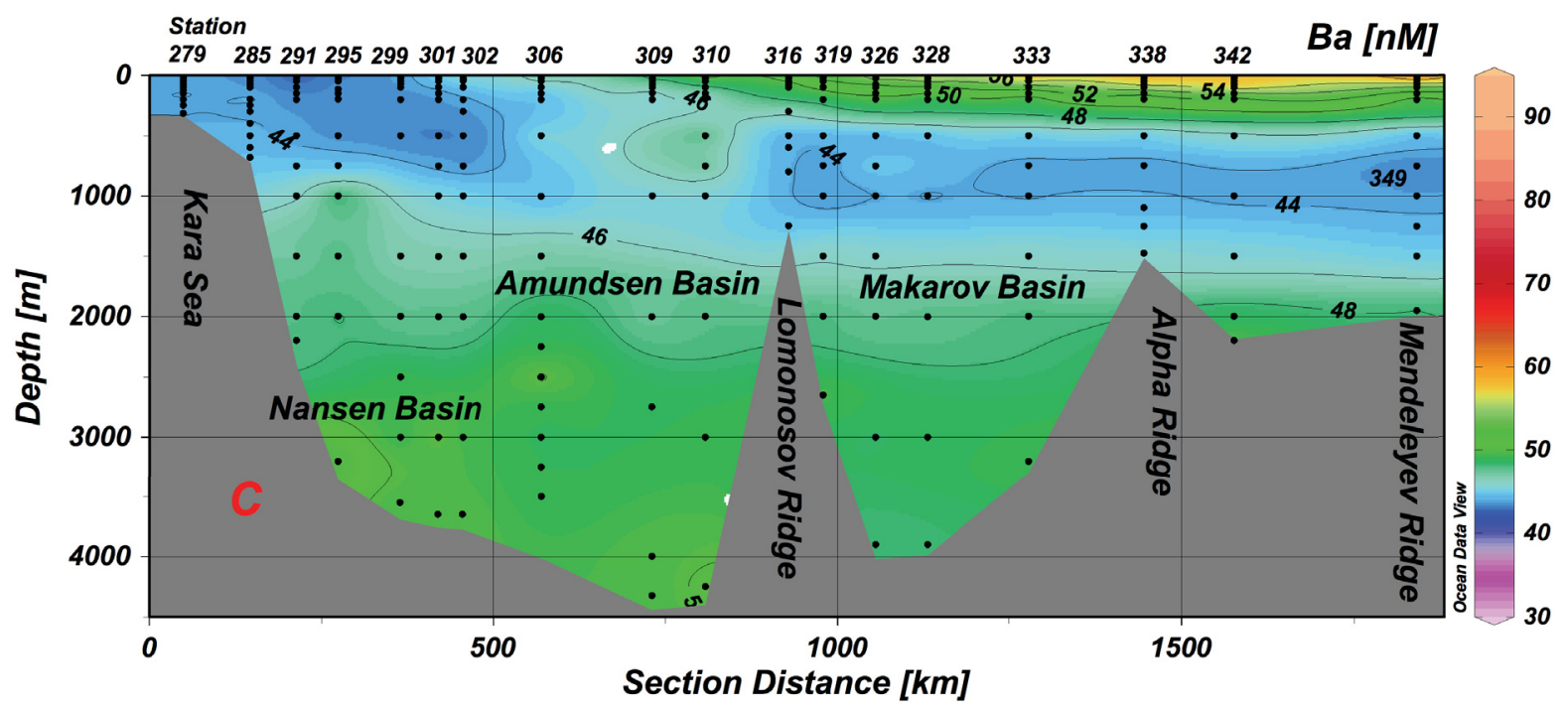

Fig. 3: Distribution of $\mathrm{Ba}$ on section $\mathrm{C}$, which includes stations 279 to 342 and reaches from the Kara Sea at $81.25^{\circ} \mathrm{N}$ to the Alpha Ridge at $84.5^{\circ} \mathrm{N}$. Its northernmost station 319 on the Lomonosov Ridge is positioned at $153.67^{\circ} \mathrm{E}$ and $88.67^{\circ} \mathrm{N}$ and is positioned in a trough with $2740 \mathrm{~m}$ depth. Isolines are at $2 \mathrm{nM}$ intervals.

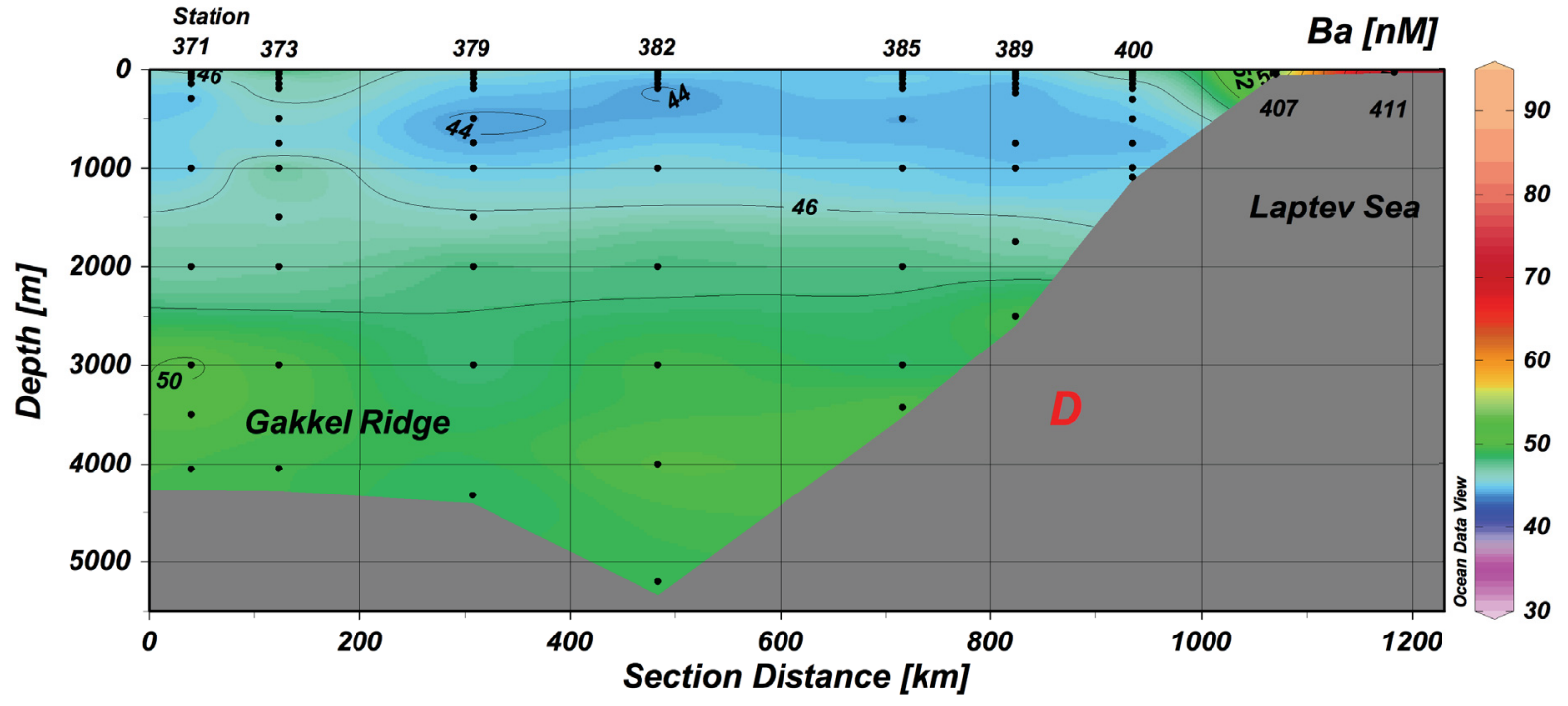

Fig. 4: Distribution of $\mathrm{Ba}$ on section $\mathrm{D}$, which includes stations 371 to 411 and reaches from the interior Eurasian Basins at $84.65^{\circ} \mathrm{N}$ to the Laptev Sea shelf at $75.2^{\circ} \mathrm{N}$ following the Gakkel Ridge. Isolines are at 2 nM intervals. 

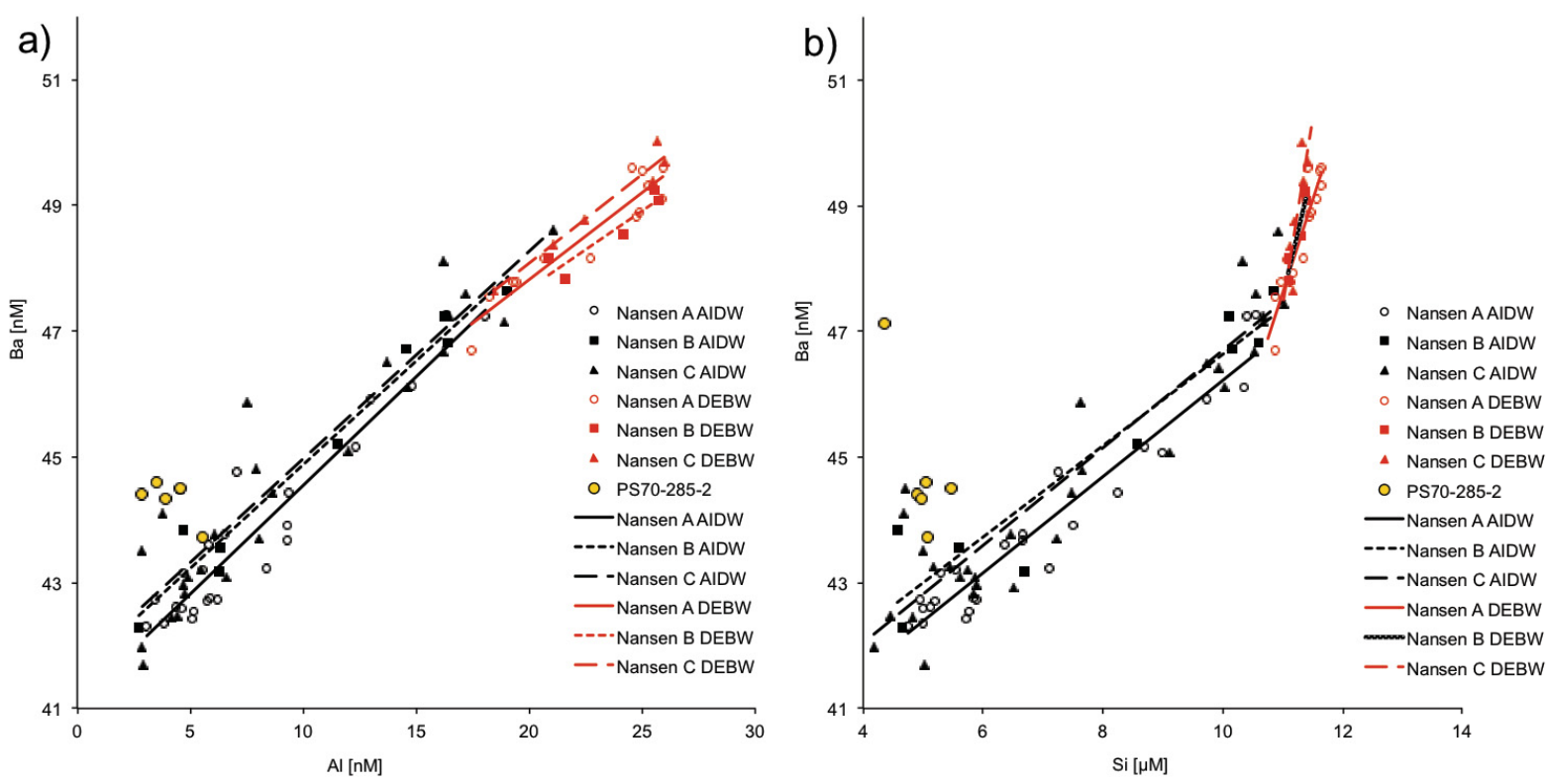

Fig. 5: Nansen Basin AIDW and DEBW of sections A to C: a) Ba vs. Al (see table 2 for respective eqns.) and b) Ba vs. Si (see table 3 for respective eqns.). Station 285 is positioned at the Kara Sea edge of section $C$ where the Barents Sea branch of the lower halocline leaves the shelf.
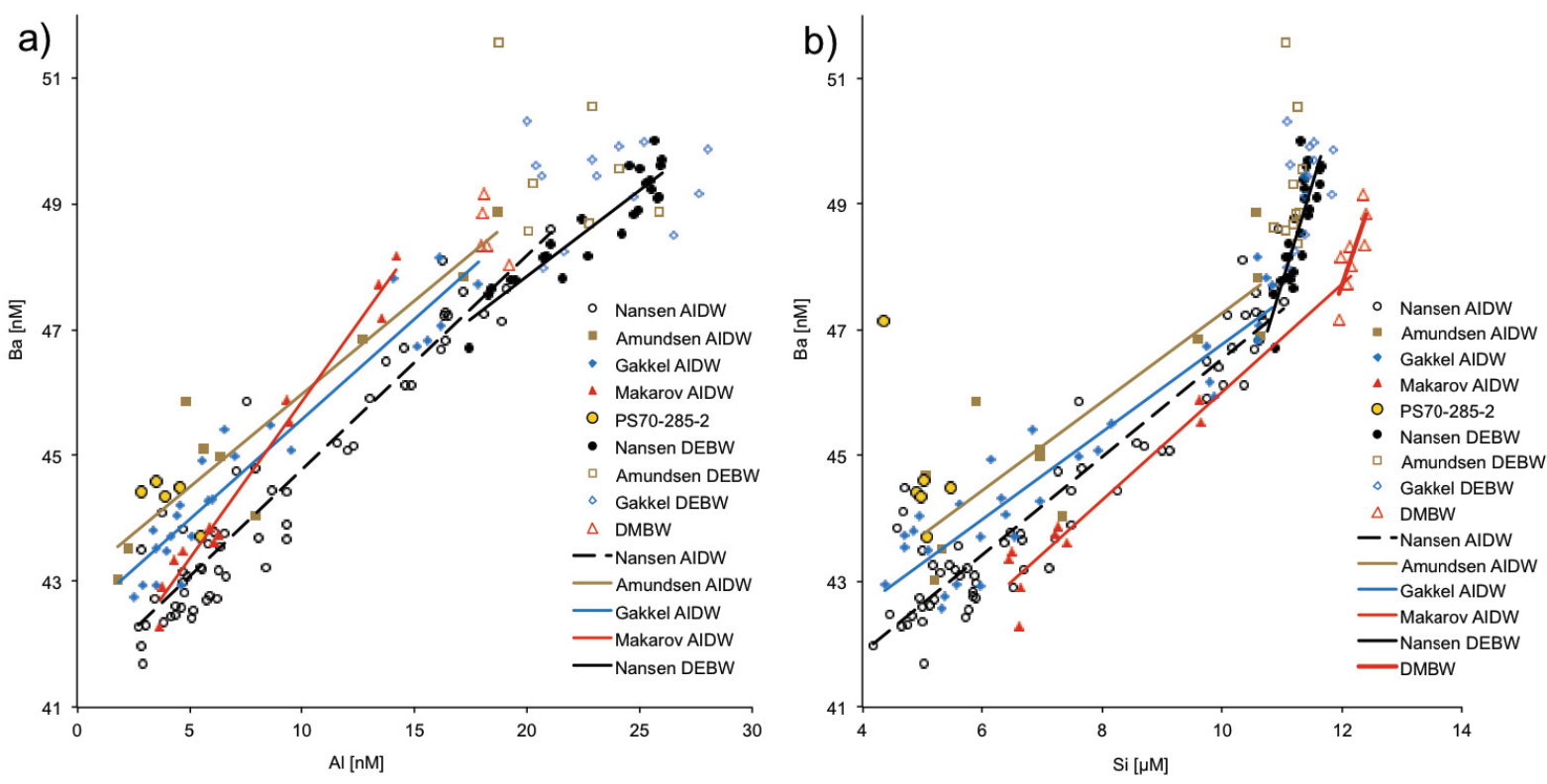

Fig. 6: AIDW, DEBW, and DMBW of sections $A$ to D. Sections $A$ to $C$ in the Nansen AIDW and DEBW were merged (cf. fig. 5). a) Ba vs. Al (see table 2 for respective eqns.). The three data points at the high end of the Makarov AIDW regression line are those from $2000 \mathrm{~m}$ depth and are assigned to the Makarov AIDW (fig. 7a) although from potential temperature they should be reckoned among the DMBW. b) Ba vs. Si (see table 3 for respective eqns.). Station 285 is positioned at the Kara Sea edge of section $\mathrm{C}$ where the Barents Sea branch of the lower halocline leaves the shelf. 

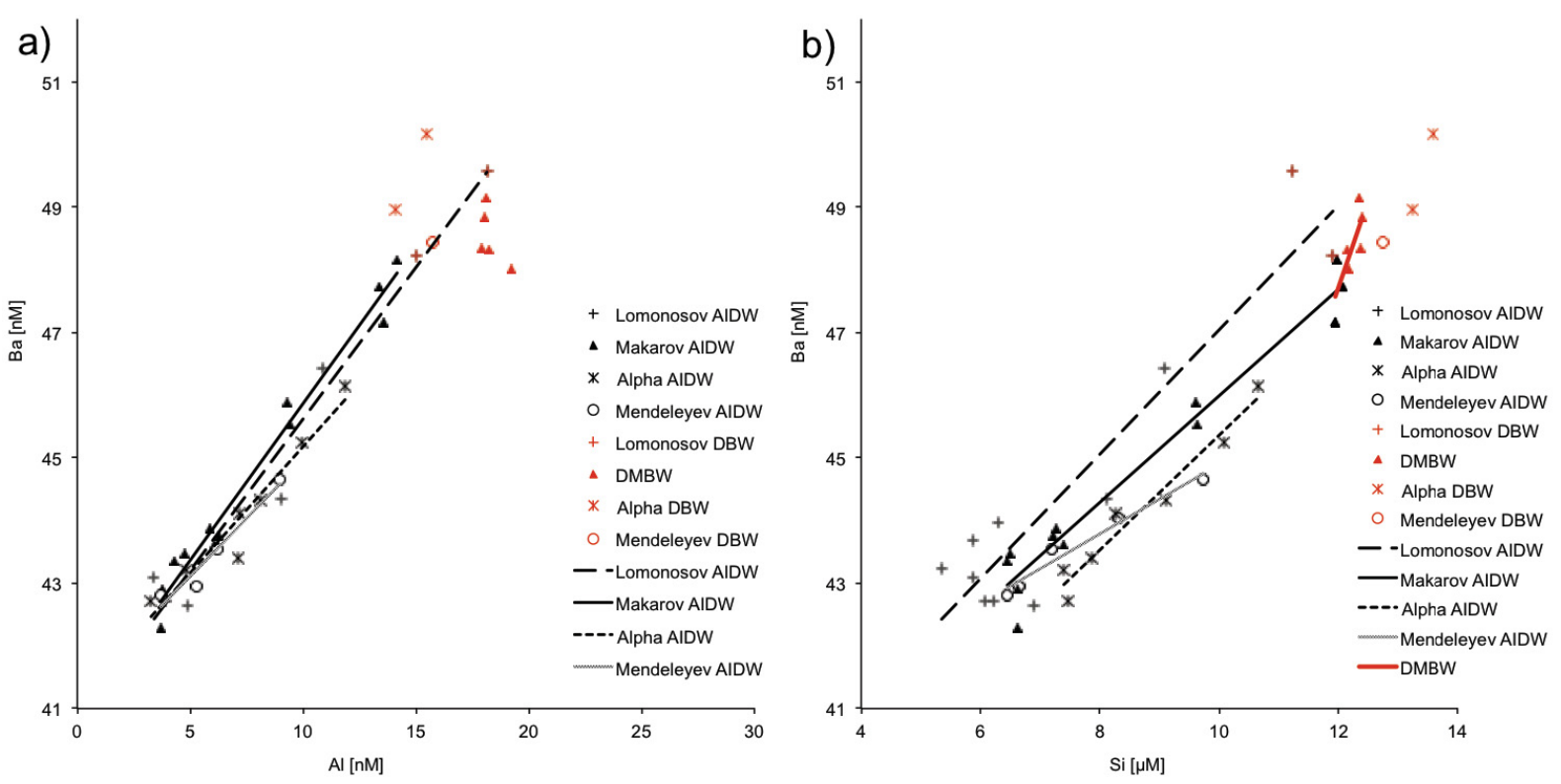

Fig. 7: Canadian AIDW and DMBW. a) Ba vs. Al (see table 4 for respective eqns.). Data of the Lomonosov and Mendeleyev DBW fit the regression line derived for the Lomonosov AIDW. Data of the Alpha Ridge DBW are far from the regression lines due to higher Ba concentrations compared with Al. b) Ba vs. Si (see table 4 for respective eqns.). The regression line of the DMBW is shown in table 3. Data from $2000 \mathrm{~m}$ of the Mendeleyev Ridge, the Alpha Ridge as well as the Lomonosov (one point each) scatter close to the extrapolated regression line derived for the Makarov AIDW. The deepest samples of the Lomonosov and Alpha ridges (one point each) are not close to this line. 


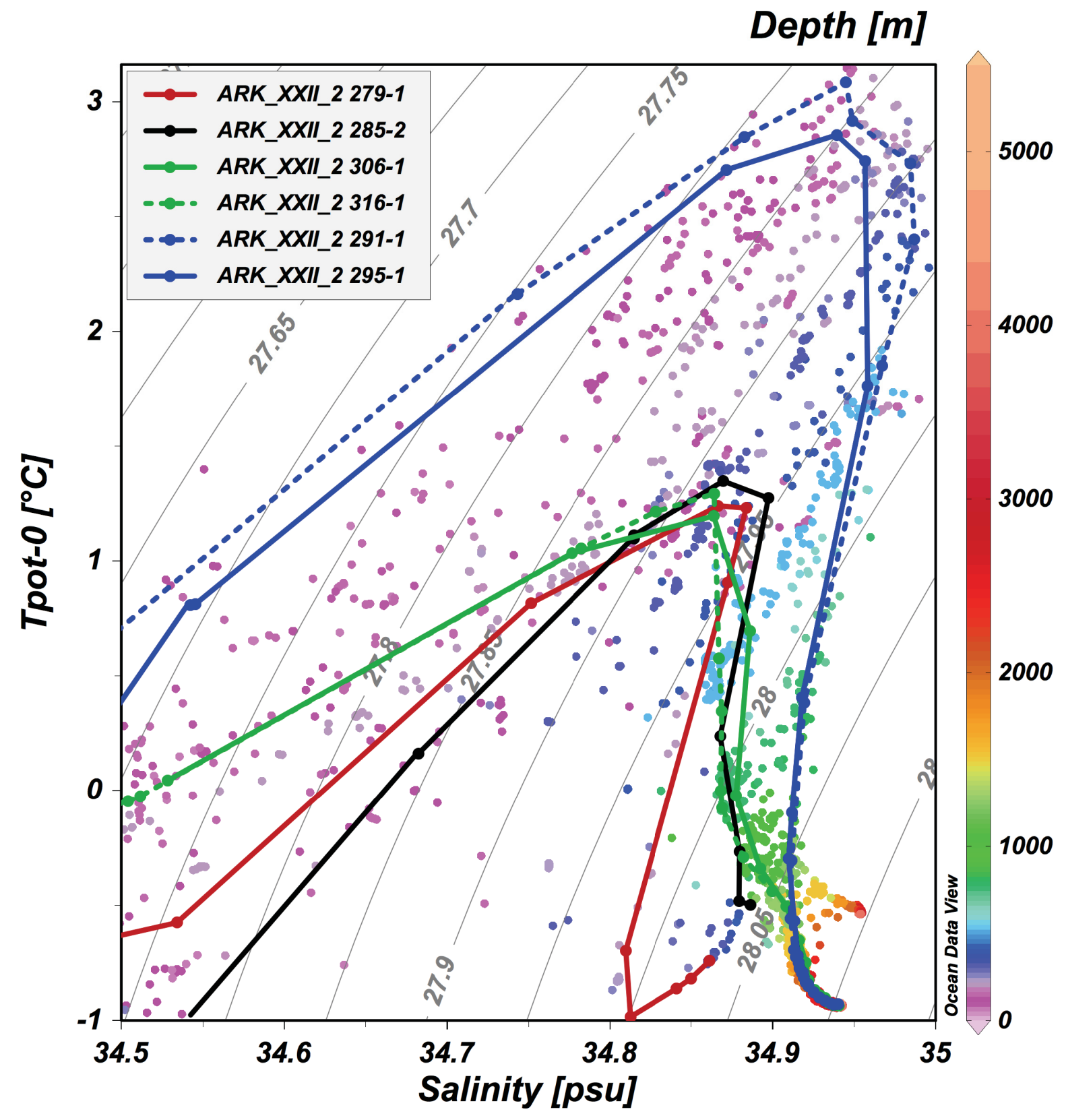

Fig. 8: Theta-S-plot of ARK-XXII/2. The 27.85 isopycnal corresponds to a depth of about $200 \mathrm{~m}$ and separates SLW from AIDW. Samples at station 285 (black line) are distinct from the stations farther offshore typically from the Fram Strait Branch of Atlantic inflow (blue lines) and resemble more the lines of the Amundsen Basin and Lomonosov Ridge area (green lines) and the Kara Sea (red line) below 200 m, showing its source as the Barents Sea Branch of the Atlantic inflow. This data is courtesy of the AWI oceanography team (see Schauer et al., 2008). 

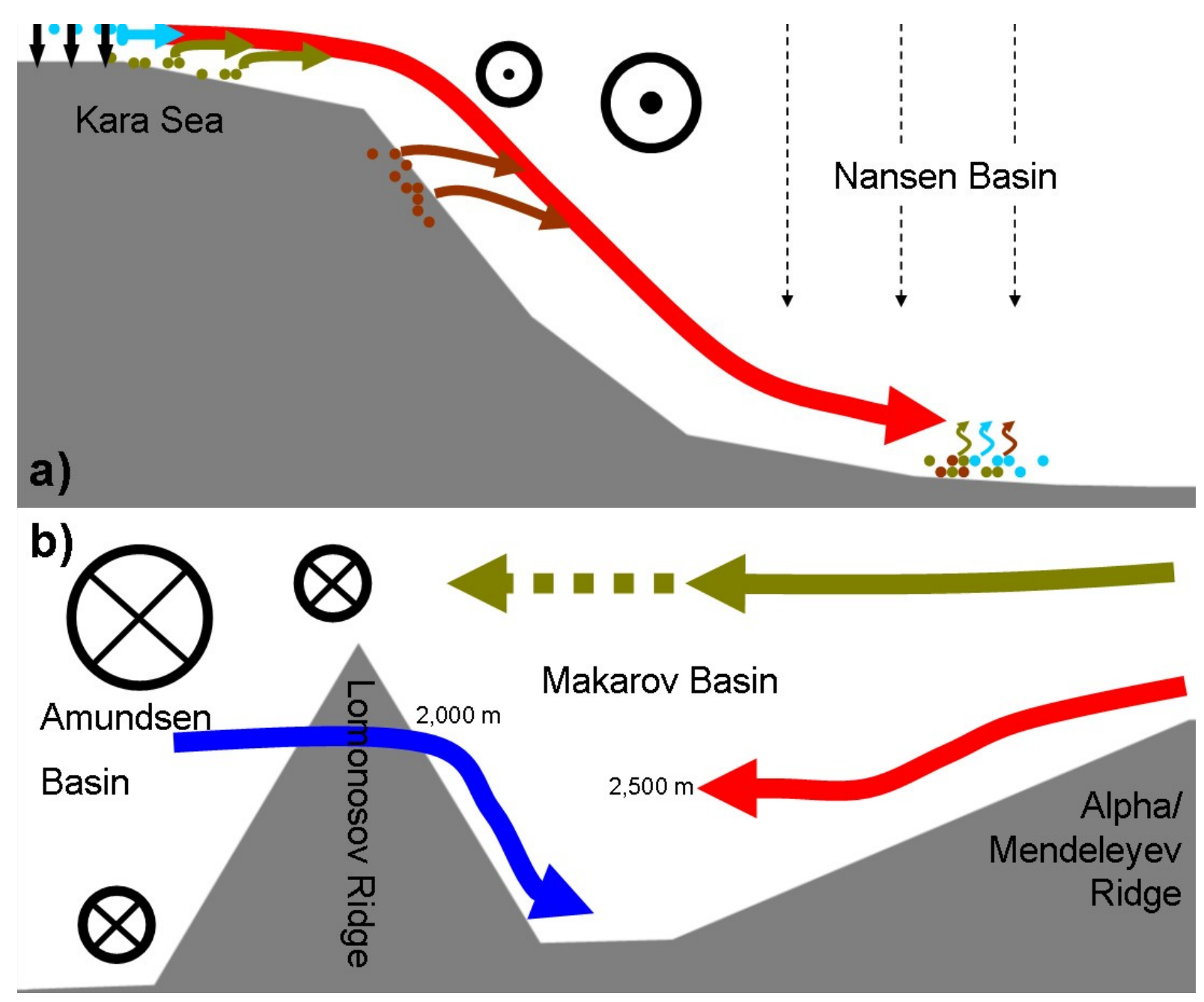

Fig. 9: Conceptual circulation model. a) The incoming Atlantic water is modified on the Barents and Kara Seas as well as in the Nansen Basin, forming two branches of lower halocline water (circles). Water from the Barents and Kara Seas is convecting down the slope (red arrow), taking with it particles from biological production (bright blue) and terrigenous particles (dark yellow) from the shelves and sediment from the slopes (brown) to the Nansen DEBW. Sedimentation flux on the shelf is higher than in the central Nansen Basin (black arrows). The halocline waters and AIDW flow along the slope of the Laptev Sea and return towards Fram Strait along the Gakkel Ridge and in the Amundsen Basin as the boundary current along the Lomonosov Ridge. A branch of the AIDW crosses the Lomonosov Ridge close to the Laptev Sea slope, entering the Canadian AIDW at 1500 m depth (not shown). b) AIDW from the boundary current (large circle) in the Amundsen Basin crosses the Lomonosov Ridge at depths below $2000 \mathrm{~m}$, sinking below $2500 \mathrm{~m}$ and diluting the DMBW (blue arrow). Moreover water from the Siberian Seas, the Canadian shelves and the Pacific enters the Makarov Basin at $2000 \mathrm{~m}$ via the Alpha and Mendeleyev ridges, sinking to 2500 $\mathrm{m}$ in the DMBW (red arrow). Above that layer ALW mixed with Pacific water is flowing into the Makarov Basin from the Mendeleyev Ridge (dark yellow arrow). 

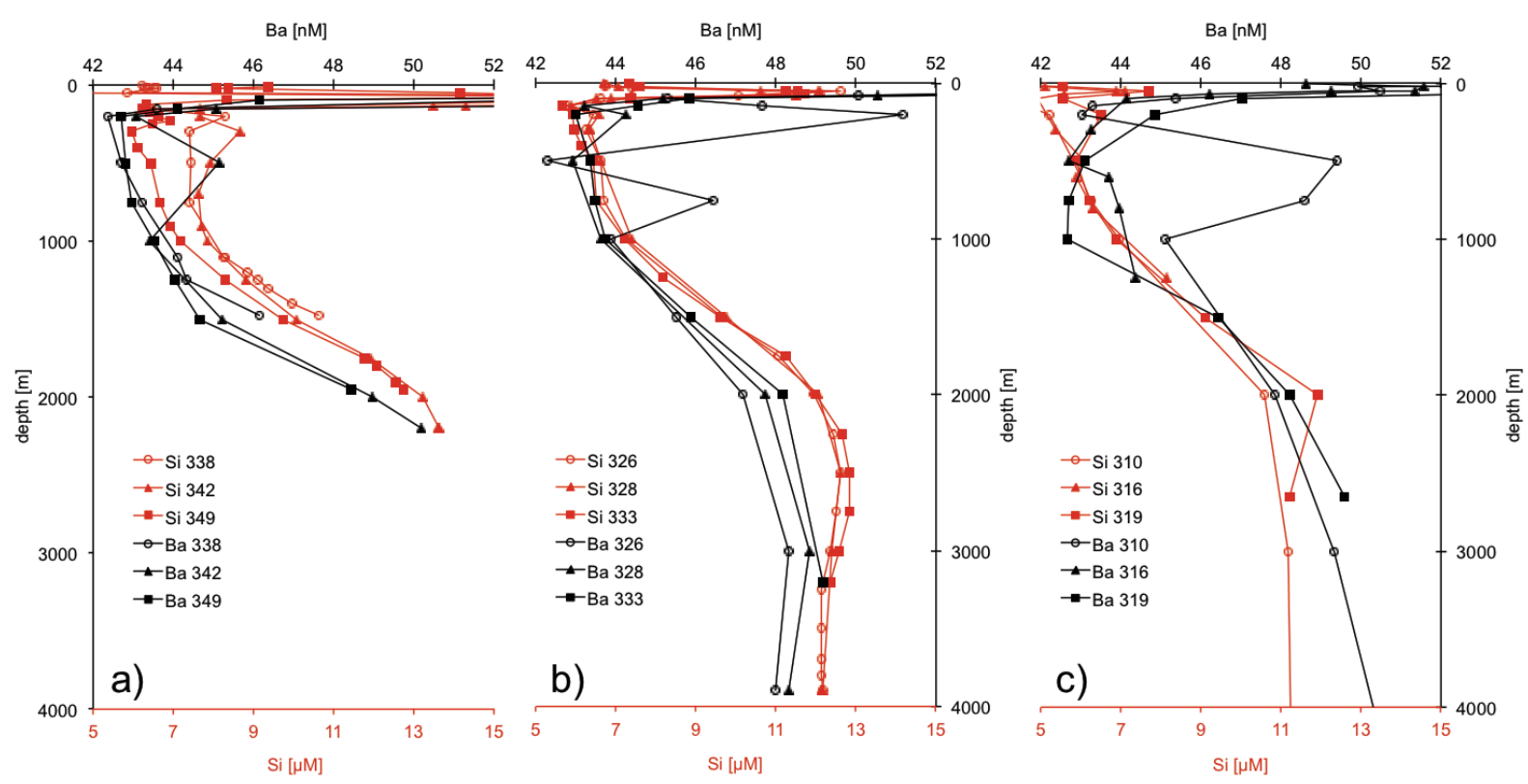

Fig. 10: Profiles of Ba and Si on a) the Alpha Ridge (stations 338, 342) and Mendeleyev Ridge (station 349) and b) the Makarov Basin (stations 326 to 333). In c) stations 316 and 319 from the Lomonosov Ridge and 310 from the Amundsen Basin are presented for comparison. 